\title{
International Law in Asia: A Bibliographic Survey 2012
}

\author{
Jeong Woo Kim \\ Research Fellow, DILA-Korea \\ Adjunct Lecturer, Law Department, Handong Global University
}

\section{INTRODUCTION}

This bibliography provides information on books, articles, notes, and other materials dealing with international law in Asia, broadly defined. Only English language publications are listed. In the preparation of this bibliography, good use has been made of the list of acquisitions of the Peace Palace Library in The Hague, The Netherlands, as well as the Washington \& Lee University law journal rankings, in addition to book reviews in journals of international law, Asian studies, and international affairs. Most, if not all, of the materials can be listed under two or more categories, but in order to save space, each item has been placed under one category.

The bibliography is limited to new materials published in 2012, or in some cases, previously published materials that have new editions in 2012. The headings used in this year's bibliography are as follows:

1. General

2. States and statehood

3. IGOs

4. NGOs

5. Territory and jurisdiction

6. Seas and marine resources

7. Rivers and water resources

8. Jus ad bellum and jus in bello

9. International criminal law and transnational crime

10. Peace and transitional justice

11. Security

12. Environment

13. Energy 
14. Development

15. Human rights - General

16. Human rights - Institutions and Organizations

17. Human rights - Central Asia

18. Human rights - South Asia

19. Human rights - Northeast Asia

20. Human rights - West Asia

21. Human rights - Southeast Asia

22. Nationality, migration and refugees

23. Colonialism and self determination

24. International economic and business law - General

25. WTO and trade

26. Investment

27. Intellectual property

28. Cultural property and heritage

29. Dispute settlement

30. Arbitration

31. Private International law

32. Internet, data and communications

33. Air and Space

34. Miscellaneous

\section{GENERAL}

Ali, Hanishi T. et al., India, 46(1) International Lawyer 553 (2012).

Carl, Beverly May, The Laws of Genghis Khan, 18(2) Law \& Business Review of the Americas 147-172 (2012).

Charyyeva, Bahar et al., Central Asia, 46(1) International Lawyer 501 (2012).

Dai, Bingguo, Asia, China and International Law, 11(1) Chinese Journal OF INTERNATIONAL LAW 1-4 (2012).

Deng, Ying et al., China, 46(1) International Lawyer 517 (2012).

The Oxford Handbook of the History of International Law (Bardo Fassbender, Anne Peters, Simone Peter \& Daniel Högger eds., Oxford University Press 2012). 
Ferasat, Anahita et al., Middle East and North Africa, 46(1) International LAW YER 601 (2012).

Mendelsohn, Barak, God vs. Westphalia: Radical Islamist Movements and the Battle for Organising the World, 38(3) REview of INTERNATIONAL STUDIES 589-613 (2012).

Mishra, Pankaj, From the Ruins of Empire: The Revolt Against the West And the Remaking of Asia (Farrar, Straus and Giroux 2012).

Pareja-Alcaraz, Pablo, International Law and East Asia's Regional Order: The Strengthening of a Fundamental Institution, in INTERNATIONAL Law in a Multipolar World (Matthew Happold ed., Routledge 2012).

Persaud, Justin G. \& Saunders, Steve, Asia/Pacific, 46(1) International LAWYER 483 (2012).

Ruskola, Teemu, The East-Asian Legal Tradition, in The CAmbridge Companion to Comparative Law (Mauro Bussani \& Ugo Mattei eds., Cambridge University Press 2012).

Salter, Michael, Law, Power and International Politics with Special Reference to East Asia: Carl Schmitt's Grossraum Analysis, 11(3) ChInEsE JouRnAL OF INTERNATIONAL LAW 393-427 (2012).

Tan, Kevin Y.L., Constitutionalism and the Search for Legal and Political Legitimacy in the Asian States, 7(2) National Taiwan University LAW REview 503 (2012).

Max Planck Encyclopedia of Public International Law (R. Wolfrum ed., Oxford University Press 2012).

\section{STATES AND STATEHOOD}

Netherlands Yearbook of International Law 2011: Agora: The Case of Iraq: International Law and Politics (I.F. Dekker and E. Hey eds., Springer 2012).

China, Democracy, and Law: A Historical and Contemporary Approach (Mireille Delmas-Marty and Pierre-Étienne Will eds., Brill 2012). 
Dumberry, Patrick, Is Turkey the 'Continuing' State of the Ottoman Empire Under International Law?, 59(2) NeTHERLA NDS InTERNATIONAL LAW REview 235 (2012).

Flaherty, Martin S., Hong Kong Fifteen Years after the Handover: One Country, Which Direction?, 51(2) Columbia Journal of TransNATIONAL LAW 275-286 (2013).

Gagain, Michael, Climate Change, Sea Level Rise, and Artificial Islands: Saving the Maldives' Statehood and Maritime Claims through the Constitution of the Oceans, 23(1) Colorado Journal of InTERnAtional Environmental LaW \& Policy 17 (2012).

Kattan, Victor, Litigating Palestine Before International Courts and Tribunals: The Prospects of Success and Perils of Failure, 35(1) Hastings International \& Comparative LAW Review 129-148 (2012).

$\mathrm{Ku}$, Julian, China and the Future of International Adjudication, 27 MARYLAND JOURNAL OF INTERNATIONAL LAW 154-178 (2012).

Li, Zhaojie, The Impact of International Law on the Transformation of China's Perception of the World: A Lesson from History, 27 MARYLAND JOURNAL OF INTERNATIONAL LAW 128-153 (2012).

Michael, Bernardo A., Statemaking and Territory in South Asia: Lessons From the ANGLO-Gorkha WAr (1814-1816) (Anthem 2012).

Nagan, Winston P. \& Haddad, Aitza M., Recognition of Palestinian Statehood: A Clarification of the Interests of the Concerned Parties, 40 Georgia Journal of International \& Comparative Law 341 (2012).

Nagan, Winston P. \& Haddad, Aitza M., The Legal and Policy Implications of the Possibility of Palestinian Statehood, 18(2) U.C. DAVIS JournAL of International LaW \& Policy 343-444 (2012).

Ottaway, Marina \& Kaysi, Danial, The State of Iraq, The Carnegie Papers: Carnegie Endowment for International Peace 1-19 (Feb. 2012).

Roth, Brad R., Parsing "Mutual Non-Recognition and Mutual Non-Denial:" An International Law Perspective on Taipei's Current Framework for Cross-Strait Relations, 30 Chinese (TAIwan) Yearbook of InterNATIONAL LAW \& AfFAirs 15 (2012). 
Sverdrup-Thygeson, Bjernar, A Neighbourless Empire - The Forgotten Diplomatic Tradition of Imperial China, 7(3) Hague Journal of DiplomaCy 245-268 (2012).

Wang, Lu, Comparative Law Scholarship in China in 2012, 1(2) Chinese Journal of Comparative LaW 365-380 (2013).

China, the European Union and Global Governance (Jan Wouters, Tanguy de Wilde, Pierre Defraigne and Jean-Christophe Defraigne eds., Edward Elgar 2012).

Xue, Hanqin, Chinese Contemporary Perspectives on International LaW: History, Culture and International LaW (Martinus Nijhoff 2012).

Zarrow, Peter, After Empire: The Conceptual Transformation of the Chinese State, 1885-1924 (Stanford University Press 2012).

Zhu, Lijiang, Chinese Practice in Public International Law: 2011, 11(3) Chinese Journal of International LaW 541-608 (2012).

Zook, Darren C., Reforming North Korea: Law, Politics, and the Market Economy, 48(1) Stanford Journal of International LaW 131184 (2012).

\section{IGOs}

Abdel-Monem, Tarik, ASEAN's Gradual Evolution: Challenges and Opportunities for Integrating Participatory Procedural Reforms for the Environment in an Evolving Rights-Based Framework, 29(2) PACIFIC Basin LaW Journal 234 (2012).

Clarke, Gerard, The Evolving ASEAN Human Rights System: The ASEAN Human Rights Declaration of 2012, 11 NORTHWESTERN JOURNAL OF International Human Rights 1 (2012).

Djafar, Zainuddin, ASEAN Competitiveness, Is Indonesia Ready Yet?, 9(4) InDONESIAN JOURNAL OF INTERNATIONAL LAW 597 (2012).

Dumper, Michael \& Larkin, Craig, The Politics of Heritage and the Limitations of International Agency in Contested Cities: A Study of the Role of UNESCO in Jerusalem's Old City, 38(1) Review OF InTERNATIONAL STUdies 25 (2012). 
ASEAN and the Institutionalization of East Asia (Ralf Emmers ed., Routledge 2012).

Ewing-Chow, Michael \& Bernard, Leonardo, The ASEAN Charter: The Legalization of ASEAN?, in Global Administrative Law: The CAsевоок (Sabino Cassese, et al., eds. Institute for Int'l Law \& Justice, NYU School of Law 3rd ed. 2012).|

Gallo, Robert, The Future of Informalism in the Economic Integration of ASEAN, 5(2) Journal of East Asia \& International LaW 495 (2012).

Lin, Shaun \& Grundy-Warr, Carl, ASEAN and Interconnecting Regional Spheres: Lessons for the Indian Ocean Region, 8(1) JournaL OF THE INDIAN OCEAN REgION 54-70 (2012).

Miyazaki, Takashi, Global Challenges and ASEAN: Major Politico-Legal Issues Facing East Asia, 9(3) Indonesian Journal of InternATIONAL LAW 1 (2012).

Naidu, G.V.C., Prospects for IOR-ARC Regionalism: An Indian Perspective, 8(1) Journal of the Indian OCEAn Region 21-36 (2012).

$\mathrm{Ng}$, Joel, Rule of Law as a Framework Within the ASEAN Community, 5(2) Journal of EAst Asia \& InTERnAtional LAw 327 (2012).

Putra, Ida Bagus Wyasa, Harmonizing Ideological Tension in the Development of the ASEAN Law, 5(2) Journal of EAST Asi A \& INTERnATIONAL LAW 359 (2012).

Rajagukguk, Erman, Harmonization of Law in ASEAN Countries Towards Economic Integration, 9(4) INDONESIAN JOURNAL OF INTERNATIONAL LAW 529 (2012).

Roberts, Christopher B., ASEAN Regionalism: Cooperation, Values AND InSTitutionAlisATION (Routledge 2012).

\section{NGOs}

Chen, Jie, Transnational Civil Society in China: Intrusion and IмPACT (Edward Elgar 2012).

Fleay, Caroline, Transnational Activism, Amnesty International and Human Rights in China: The Implications of Consistent Civil and 
Political Rights Framing, 16(7) International Journal of Human Rights 915 (2012).

Gunter, Michael M. Jr. \& Rosen, Ariane C., Two-Level Games of International Environmental NGOs in China, 3(2) William \& Mary Policy REVIEW 270-294 (2012).

Han, Junhong \& Holly, Amelia Snape, Analysis of Chinese Grassroots AIDS Prevention NGOs' Organizational Compliance and Development Strategies - Working from the Example of the Shanghai YAPSC, 4(2) China Nonprofit Review 259-274 (2012).

Han, Junkui, Foreign NGOs in China in the Context of a Global Civil Society - With a Discussion of the Internationalization of Chinese NGOs, 4(1) China Nonprofit Review 3-24 (2012).

Moffa, Anthony L. I., Two Competing Models of Activism, One Goal: A Case Study of Anti-Whaling Campaigns in the South Ocean, 37(1) Yale Journal of International Law 201-214 (2012).

Noakes, Stephen, Transnational Advocacy Networks and Moral Commitment: The Free Tibet Campaign Meets the Chinese State, 67(2) INTERNATIONAL JOURNAL 507-526 (2012).

Orr, Zvika, The Adaptation of Human Rights Norms in Local Settings: Intersections of Local and Bureaucratic Knowledge in an Israeli NGO, 11(2) Journal of Human Rights 243 (2012).

Steinberg, Gerald M. \& Herzberg, Anne \& Berman, Jordan, Best Practices for Human Rights and Humanitarian NGO FactFINDING (Martinus Nijhoff 2012).

Steinberg, Gerald M., International NGOs, the Arab Upheaval, and Human Rights: Examining NGO Resource Allocation, 11 NorThWESTERN Journal of International Human Rights 126 (2012).

\section{TERRITORY AND JURISDICTION}

Junngam, Nartnirun, The Secessionist Movement in the Southernmost Provinces of Thailand: A View from the New Haven School of International Law, 20(2) Asia Pacific Law Review 233-255 (2012). 
Madokoro, Laura, Borders Transformed: Sovereign Concerns, Population Movements and the Making of Territorial Frontiers in Hong Kong, 1949-1967, 25(3) Journal of Refugee Studies 407-427 (2012).

Mushkat, Roda, Chinese Border Disputes Revisited: Toward a Better Interdisciplinary Synthesis, 12(1) RICHMOND JournaL OF GLOBAL LAW \& Business 45-90 (2012).

Satoh, Yayohi, Japanese Court Cases Involving East Asian Citizens and Corporations: Part One : Law Applicable to Personal Status of Korean and Chinese National Before Japanese Courts, 55 Japanese YearBOOK OF INTERNATIONAL LAW 323-370 (2012).

Tang, Zheng Sophia, Effectiveness of Exclusive Jurisdiction Clauses in the Chinese Courts - A Pragmatic Study, 61(2) International \& Comparative Law Quarterly 459-484 (2012).

Traviss, Alexandra C., Temple of Preah Vihear: Lessons on Provisional Measures, 13(1) Chicago Journal of International LAw 317-344 (2012).

Walter Woon, Resolving Territorial Disputes in ASEAN, 30 CHInese (Tainan) Yearbook of International LaW \& Affairs 1 (2012).

Zhang, Zuxing, A Deconstruction of the Notion of Acquisitive Prescription and its Implications for the Diaoyu Islands Dispute, 2(2) AsIAN JOURNAL OF INTERNATIONAL LAW 323-338 (2012).

\section{SEAS AND MARINE RESOURCES}

Agnihotri, Kamlesh K., Protection of Trade and Energy Supplies in the Indian Ocean Region, 8(1) Maritime Affairs 13-30 (2012).

Ashraf, A.S.M. Ali, Trans-Boundary Water Disputes in Africa, Europe, and South Asia: A Comparative Analysis, 16 Journal of InTERnAtional AfFAirs 1 (2012).

Bagheri, Parviz et al., Legal Rules for Marine Trading Between Persian Gulf with the East of Asia in 16th Century, 9(3) US-China Law Review 202-210 (2012).

Balaram, Ravi A., Case Study: The Myanmar and Bangladesh Maritime Boundary Dispute in the Bay of Bengal and its Implications for South 
China Sea Claims, 31(3) Journal of Current Southeast Asian AfFairs 85 (2012).

Bang, Ho-Sam \& Jang, Duck-Jong, Recent Developments in Regional Memorandums of Understanding on Port State Control, 43(2) OCEAN Development \& International LAW 170 (2012).

Bernard, Leonardo, Whose Side is It On? The Boundaries Dispute in the North Malacca Strait, 9(3) Indonesian JournAL OF INTERNATIONAL LAW 381-408 (2012).

Blazevic, Jason J., Navigating the Security Dilemma: China, Vietnam, and the South China Sea, 31(4) Journal of Current Southeast Asian AfFAirs 79 (2012).

Casey, Allison \& Sussex, Matthew, Energy Transit States and Maritime Security in the Malacca Strait: The Case of Singapore, 4(1) Australian Journal of Maritime \& OCEAn Affairs 25-36 (2012).

Chang, Yen-Chiang, A Note on a Comparison of the Ocean Governance System Between Mainland China and Taiwan, 43(4) Ocean DevelOPMENT \& INTERNATIONAL LAW 311-329 (2012).

Chen, Chen-Ju, Multipolar Disorder in the East China Sea: Learning from the Experiences in Building the Legal Systems of the Arctic and the Antarctic, 30 Chinese (Taiwan) Yearbook of International LaW \& Affairs 107 (2012).

Chen, Gang, China's Emerging Arctic Strategy, 2(2) Polar Journal 358371 (2012).

Churchill, Robin, Bangladesh/Myanmar Case: Continuity and Novelty in the Law of Maritime Boundary Delimitation Case Analysis, 1(1) CAmbridge Journal of International \& Comparative LAW 137 (2012).

Cozens, Peter, 17th International Sea Lines of Communication Conference, Taipei, Taiwan, 25-26 September 2012, 4(4) Austr Alian Journal of Maritime \& Ocean Affairs 141-142 (2012).

Dimento, Joseph F.C. \& Hickman, Alexis Jaclyn, Environmental Governance of the Great Seas: Law and Effect (Edward Elgar 2012). 
Dirhamsyah, IUU Fishing in Indonesia's Live Reef Fisheries, 4(2) Australian Journal of Maritime \& Ocean Affairs 44-52 (2012).

Franckx, Erik \& Benatar, Marco, Dots and Lines in the South China Sea: Insights from the Law of Map Evidence, 2(1) Asian JournaL of INTERNATIONAL LAW 89-118 (2012).

Franckx, Erik, Fisheries in the South China Sea: A Centrifugal or Centripetal Force?, 11(4) Chinese Journal of International LAW 727-747 (2012).

$\mathrm{Fu}$, Tingzhong, The Participation of Foreign Businesses in the Salvage of Sunken Vessels and Articles in China's Coastal Waters: A Legal Analysis, 2012(16) China Oceans Law Review 32 (2012).

Gadihoke, Neil, Arctic Melt: The Outlook for India, 8(1) Maritime AfFAIRS 1-12 (2012).

Gau, Michael Sheng-Ti, Recent Decisions by the Commission on the Limits of the Continental Shelf on Japan's Submission for Outer Continental Shelf, 11(3) Chinese Journal of International Law 487-504 (2012).

Gau, Michael Sheng-Ti, The U-Shaped Line and a Categorization of the Ocean Disputes in the South China Sea, 43(1) Ocean Development \& INTERNATIONAL LAW 57 (2012).

Geng, Jing, The Legality of Foreign Military Activities in the Exclusive Economic Zone Under UNCLOS, 28(74) Utrecht Journal OF INTERNATIONAL \& EUROPEAN LAW 22 (2012).

George, Mary, Adequacy of National Laws for Malaysian Ocean Governance for the Next Decade, 40 International Journal of Legal INFORMATION 202 (2012).

George, Mary, Fisheries Protections in the Context of the Geo-Political Tensions in the South China Sea, 43(1) Journal of Maritime Law \& Commerce 85-128 (2012).

Gunasekaran, Periasamy, Malaysian Port Security: Issues and Challenges, 4(2) Australian Journal of Maritime \& Ocean Affairs 56 (2012).

Hayashi, Moritaka, Military Activities in the Exclusive Economic Zones of Foreign Coastal States, 27(4) International Journal of Marine \& Coastal Law 795 (2012). 
Hong, Nong, UNClOS and Ocean Dispute Settlement: Law and Politics in the South China Sea (Routledge 2012).

Huirong, Liu \& Yue, Dong \& Yitong, Chen, China and the Arctic: The Path of Scientific Research, Law and Policy, 26 Ocean Yearbook 361-380 (2012).

Johnston, Phil, Security of Maritime Trade: A Cooperative and Coordinated Approach for the Indo-Pacific Region, 4(1) Australian Journal of Maritime \& Ocean Affairs 1-10 (2012).

Kao, Shih-Ming \& Pearre, Nathaniel Sifford \& Firestone, Jeremy, Regional Cooperation in the South China Sea: Analysis of Existing Practices and Prospects, 43(3) Ocean Development \& International LaW 283-295 (2012).

Kaur, Cheryl Rita, Regional Anti-Fish Bombing Symposium, 22-23 February 2012, Kota Kinabalu, Sabah, Malaysia, 4(2) Australian Journal of Maritime \& Ocean Affairs 53-55 (2012).

Kelly, Michael J., United States Ratification of the Law of the Sea Convention: Securing Our Navigational Future While Managing China's Blue Water Ambitions, 45(1) Case Western Reserve Journal of INTERNATIONAL LAW 461-472 (2012).

Kim, Suk Kyoon, China and Japan Maritime Disputes in the East China Sea: A Note on Recent Developments, 43(3) Ocean Development \& INTERNATIONAL LAW 296-308 (2012).

Kim, Suk Kyoon, Illegal Chinese Fishing in the Yellow Sea: A Korean Officer's Perspective, 5(2) Journal of East Asia \& International LAW 455 (2012).

Kraska, James, I.O. 2.0: Indian Ocean Security and the Law of the Sea, 43(2) Georgetown Journal of International Law 433-494 (2012).

Kwiatkowska, B., Fundamental Principle of 'without Prejudice' in Submissions to the UN CLCS in Northeast and Southeast Asia, 3(1) LAW of the SeA Reports 31 (2012).

Lee, Keun-Gwan, Recent Developments of Maritime Delimitation in Northeast Asia from an International Law Perspective, in MARITIME Border Diplomacy (Myron H. Nordquist \& John Norton Moore eds., Martinus Nijhoff 2012). 
Liu, Wen-Hong \& Kao, Jui-Chung, Marine and Coastal Management in Taiwan from the Perspective of ICZM Principles, 2012(15) China Oceans Law Review 194 (2012).

Magnusson, B.M., International Tribunal for the Law of the Sea: Judgement in the Dispute Concerning Delimitation of the Maritime Boundary Between Bangladesh and Myanmar in the Bay of Bengal (14 March 2012), 27(3) International Journal of Marine \& Coastal Law 623 (2012).

Masahiro, Miyoshi, China's "U-Shaped Line" Claim in the South China Sea: Any Validity Under International Law?, 43(1) OCEAn DevelopMENT \& INTERNATIONAL LAW 1-17 (2012).

Mohan, C. Raja, Samudra Manthan: Sino-Indian Rivalry in the Indo-PACIFIC (Carnegie Endowment for International Peace 2012).

Nguyen Dang, Thang, Fisheries Co-operation in the South China Sea and the (Ir)relevance of the Sovereignty Question, 2(1) Asian JournaL of INTERNATIONAL LAW 59-88 (2012).

Odom, Jonathan G., A China in the Bull Shop - Comparing the Rhetoric of a Rising China with the Reality of the International Law of the Sea, 17(2) OcEan \& Coastal Law Journal 201-252 (2012).

Approaches to International LaW and the Legacy of Colonialism: The Law of the Sea, Territorial Disputes and International Dispute Settlement (In-Hyun Paik, Seokwoo Lee \& Kevin Y.L. Tan eds., Routledge 2012).

Park, Chang-Seok \& PArk, Eung-Kyuk, Korean Maritime SoverEIGNTy (Korean Institute of Public Administration 2012).

Pedrozo, Raul, The Building of China's Great Wall at Sea, 17(2) OcEAN \& Coastal Law Journal 253-290 (2012).

Poernomo, R. Panji Raditya, Sustainable Tuna Fisheries: Indonesia Perspective, 9(4) Indonesi AN Journal of International LAW 539 (2012).

Puthucherril, Tony George, Adapting to Climate Change and Accelerated Sea-Level Rise through Integrated Coastal Zone Management Laws: A Study of the South Asian Experience, 26(1) OCEAn Yearbook 533 (2012). 
Rangreji, Luther, Bangladesh-Myanmar Maritime Boundary Delimitation Dispute, 16 Journal of International Affairs 33 (2012).

Ravindran, Madhu Sudan, China's Potential for Economic Coercion in the South China Sea Disputes: A Comparative Study of the Philippines and Vietnam, 31(3) Journal of Current Southeast Asian Affairs 105 (2012).

Rusli, Mohd Hazmi bin Mohd, Bridges Across Critical International Shipping Ways: A Study of the Proposed Strait of Malacca Bridge, 15 China Oceans Law Review 14-28 (2012).

Maritime Energy Resources in Asia: Legal Regimes and CooperaTION (Clive Schofield ed., National Bureau of Asian Research 2012).

Singh, Amit, South China Sea Disputes: Regional Issue, Global Concerns, 8(1) Maritime Affairs 116-135 (2012).

Sodik, Dikdik Mohamad, The Indonesian Legal Framework on Baselines, Archipelagic Passage, and Innocent Passage, 43(4) Ocean DevelopMENT \& INTERNATIONAL LAW 330-341 (2012).

Song, Guan, Particularly Sensitive Sea Area: A Possible Approach of Cooperation in the South China Sea, 2012(16) China Oceans LaW REVIEW 63 (2012).

Song, Yann-Huei, Sovereignty and Maritime Disputes in the South China Sea: Potential Conflicts Between China and the United States, 2012(16) China Oceans Law Review 112 (2012).

Su, Jinyuan, The Proliferation Security Initiative (PSI) and Interdiction at Sea: A Chinese Perspective, 43(1) Ocean Development \& InterNATIONAL LAW 96 (2012).

Sulong, Rini Suryati, The Kra Canal and Southeast Asian Relations, 31(4) Journal of Current Southeast Asian Affairs 109 (2012).

Sultana, Razia, Development of China and Indian Ocean Economies, 16 Journal of International AfFairs 109 (2012).

Takei, Yoshinobu, Law and Policy for International Submarine Cables: An Asia-Pacific Perspective, 2(2) Asian Journal of International LAW 205-233 (2012). 
VanderZwaag, David L. \& Dang, Vu Hai, Regional Cooperation in the South China Sea and the Arctic: Lessons to be Learned?, in The Regulation of International SHipping: InTERnATIONAL AND CoMparative Perspectives: Essays in Honor of Edgar Gold (Aldo Chircop, Norman Letalik, Ted L. McDorman, \& Susan J. Rolston eds., Martinus Nijhoff 2012).

Vu, Hai Dang, Towards a Regional MPA Network in the South China Sea: General Perspectives and Specific Challenges, 26(1) Ocean YearBоOK 291 (2012).

Climate Change and The Oceans: Gauging the Legal and Policy Currents in the Asia Pacific and Beyond (Robin Warner \& Clive Schofield eds., Edward Elgar 2012).

Xiaolin, Chu \& Fu, Kuen-Chen, Planning and Studies on the Development of Fisheries Resources in the South China Sea via Cross-Strait Cooperation, 2012(16) China Oceans Law Review 9 (2012).

Yang, Zewei, The Freedom of Navigation in the South China Sea: An Ideal or a Reality?, 3 Beijing Law Review 137 (2012).

Yang, Zewei, The Present and Future of the Sino-South Korean Fisheries Dispute: A Chinese Lawyer's Perspective, 5(2) Journal of EAst Asia \& INTERNATIONAL LAW 479 (2012).

You, Ki-Jun, The Law and Practice Relating to Marine Scientific Research in Northeast Asia, in The Law of the Sea Convention: US AcCession and Globalization (Myron H. Nordquist, John Norton Moore, Alfred H.A. Soons \& Hak-So Kim eds., Martinus Nijhoff 2012).

Zeidman, Samuel J., Sittin' on the Dhaka the Bay: The Dispute Between Bangladesh and Myanmar and its Implications for the International Tribunal for the Law of the Sea, 50 Columbia Journal of TransNATIONAL LAW 442-489 (2012)

Zheng, Zhihua, Myanmar as an Important Pivot for China's Indian Ocean Strategy: A Summary of the Conference on Oceanic Relations Between Myanmar and China, 2012(16) China Oceans Law Review 162 (2012).

Zhou, Xinchao, Conference on Conservation and Development on Fishery Resources in the South China Sea: A Summary Report, 2012(16) China Oceans Law Review 185 (2012). 
Zou, Keyuan, China and the United Nations Convention on the Law of the Sea: Recent Developments and Prospects, 26 Ocean Yearbook 161 (2012).

Zou, Keyuan, China's U-Shaped Line in the South China Sea Revisited, 43(1) Ocean Development \& International Law 18-34 (2012).

\section{RIVERS AND WATER RESOURCES}

Evans, Alexandra E.V. et al., Water Quality: Assessment of the Current Situation in Asia, 28(2) International Journal of WATER Resources Development 195-216 (2012).

Joshi, Yugal Kishore \& Tortajada, Cecilia \& Biswas, Asit K., Cleaning of the Singapore River and Kallang Basin in Singapore: Economic, Social, and Environmental Dimensions, 28(4) InTERnATIONAL Journal of Water Resources Development 647-658 (2012)

Kirschner, Adele J. \& Tiroch, Katrin, The Waters of Euphrates and Tigris: An International Law Perspective, 16(1) Max Planck Yearbook of United Nations Law 329 (2012).

Landberg, Sophie, Sustainable Development of Water Resources in the Mekong River Basin: Legal and Policy Implications of Dams in the Regional Context, 5(1) Journal of East Asia \& International LAW 235 (2012).

Libert, Bo \& Lipponen, Annukka, Challenges and Opportunities for Transboundary Water Cooperation in Central Asia: Findings from UNECE's Regional Assessment and Project Work, 28(3) InTERnATIONAL Journal of Water Resources Development 565-576 (2012).

Myint, Tun, Governing International Rivers: Polycentric Politics In The MeKong AND The Rhine (Edward Elgar 2012).

Nickum, James E., Exploring the Boundaries of Water Quality Management in Asia, 28(2) International Journal of Water Resources Development 233-245 (2012).

Olsson, Oliver \& Wegerich, Kai \& Kabilov, Firdavs, Water Quantity and Quality in the Zerafshan River Basin: Only an Upstream Riparian Problem?, 28(3) International Journal of Water Resources DeVElopment 493-505 (2012). 
Rahaman, Muhammad Mizanur, Principles of Transboundary Water Resources Management and Water-related Agreements in Central Asia: An Analysis, 28(3) International Journal of Water Resources Development 475-491 (2012).

Stucki, Virpi \& Sojamo, Suvi, Nouns and Numbers of the Water-EnergySecurity Nexus in Central Asia, 28(3) International Journal of Water Resources Development 399-418 (2012).

Stucki, Virpi et al., Introduction: Water and Security in Central AsiaSolving a Rubik's Cube, 28(3) International Journal of Water Resources Development 395-397 (2012).

Suhardiman, Diana \& Giordano, Mark \& Molle, François, Scalar Disconnect: The Logic of Transboundary Water Governance in the Mekong, 25(6) Society \& Natural Resources 572 (2012).

Tanaka, Yoshifumi, Note on the Interim Measures in the Indus Waters Kishenganga Arbitration, 11(3) The LaW \& Practice of International Courts \& Tribunals 555-579 (2012).

Upadhyay, Surya Nath, International Watercourses Law and a Perspective in Nepal-India Cooperation (Ekta Books 2012).

Varis, Olli \& Kummu, Matti, The Major Central Asian River Basins: An Assessment of Vulnerability, 28(3) InTERnational Journal of Water Resources Development 433-452 (2012).

Wegerich, Kai et al., Is It Possible to Shift to Hydrological Boundaries? The Ferghana Valley Meshed System, 28(3) InTERnational Journal of Water Resources Development 545-564 (2012).

Wegerich, Kai et al., Meso-level Cooperation on Transboundary Tributaries and Infrastructure in the Ferghana Valley, 28(3) InternationaL Journal of Water Resources Development 525-543 (2012).

Zawahri, Neda A. \& Hensengerth, Oliver, Domestic Environmental Activists and the Governance of the Ganges and Mekong Rivers in India and China, 12(3) International Environmental Agreements: Politics, LaW And Economics 269 (2012).

Ziganshina, Dinara, International Water Law in Central Asia: The Nature of Substantive Norms and What Flows from It, 2(1) Asian JournaL of International LAW 169-192 (2012). 


\section{JUS AD BELLUM AND JUS IN BELLO}

Ali, Lubna Abid, Transition in Afghanistan: Imperatives Handling Internal and External Security Challenges, 9(1) International Studies JOURNAL 135 (2012).

Ambos, Kai \& Alkatout, Josef, Has 'Justice Been Done'? The Legality of Bin Laden's Killing Under International Law, 45(2) Israel LAW Review 341-366 (2012).

Baker, Alan, International Humanitarian Law, ICRC and Israel's Status in the Territories, 94(888) International Review of the Red Cross 1511-1521 (2012).

Bellal, Annyssa \& Doswald-Beck, Louise, Evaluating the Use of Force during the Arab Spring, 14 Yearbook of International HumanitarIAN LAW 3-15 (2011) (T.M.C. Asser 2012).

Buchan, R., The Palmer Report and the Legality of Israel's Naval Blockade of Gaza, 61(1) International \& Comparative LaW Quarterly 264 (2012).

Chatur, Dharmendra \& Jagannath, Shruthi, The Red Terror and a State of Uncertainty: United Nations' Role in the Indian Maoist Struggle, 12(2) Global Jurist (2012) (2012), http://www.degruyter.com/view/j/ gj.2012.12.issue-2/1934-2640.1406/1934-2640.1406.xml..

Cronogue, Graham, Responsibility to Protect: Syria the Law, Politics, and Future of Humanitarian Intervention Post-Libya, 3(1) Journal of International Humanitarian Legal Studies 124-159 (2012).

Di Mauro, D., The UN and the Arab-Israeli Conflict: American Hegemony and UN Intervention SinCe 1947 (Routledge 2012).

Ferrer, Raymundo B. \& Cabangbang, Rmldolph G., Non-International Armed Conflicts in the Philippines, 88 International Law StudIES 263 (2012).

Garwood-Gowers, Andrew, China and the "Responsibility to Protect": The Implications of the Libyan Intervention, 2(2) AsIan Jour NAL OF INTERNATIONAL LAW 375-393 (2012).

Geoxavier, Bernard Yudkin, China as Peacekeeper: An Updated Perspective on Humanitarian Intervention, 7(2) Yale Journal of InterNATIONAL AfFairs 98-101 (2012). 
Gifkins, Jess, The UN Security Council Divided: Syria in Crisis, 4(3) Global Responsibility to Protect 377-393 (2012).

Harris, Albert, Settlers and Insurgency: The Philippines and Sri Lankan Cases, 8(31) Review of International Law \& Politics 103 (2012).

Hover, Matthew R., The Occupation of Iraq: A Military Perspective on Lessons Learned, 94(885) International Review of the Red Cross 339-346 (2012).

Howe, Zoë, Can the 1954 Hague Convention Apply to Non-state Actors?: A Study of Iraq and Libya, 47(2) Texas InTERnAtional Law JournaL 403-425 (2012).

Lee, Pak K. \& Chan, Gerald \& Chan, Lai-Ha, China in Darfur: Humanitarian Rule-Maker or Rule-Taker?, 38(2) Review of InTERNATIONAL STUdies 423 (2012).

Liu, Daqun, Chinese Humanitarian Law and International Humanitarian Law, in The Diversification and Fragmentation of International Criminal Law 347 (Larissa Herik \& Carsten Stahn eds., Martinus Nijhoff 2012).

Marshall, Jonathan V., The Lebanese Connection: Corruption, Civil War, and the International Drug Traffic (Stanford University Press 2012).

Maurer, Peter, Challenges to International Humanitarian Law: Israel's Occupation Policy, 94(888) International Review of the Red Cross 1503-1510 (2012).

McLaughlin, Rob, An Australian Perspective on Non-International Armed Conflict: Afghanistan and East Timor, 88 International Law Studies 293 (2012).

Moorcraft, Paul, Total destruction of the Tamil Tigers: The Rare Victory of SRi LAnka's Long War (Pen and Sword Military 2012).

Murphy, Martin N., The Abundant Sea: Prospects for Maritime Non-State Violence in the Indian Ocean, 8(2) Journal OF THE INDIAN OCEAN REgION 173-187 (2012).

Nam, Seunghyun Sally, War on the Korean Peninsula? Application of Jus in Bello in the Cheonan and Yeonpyeong Island Attacks, 8(1) EAsT Asia Law Review 43 (2012). 
Nikitin, M.B., North Korea's Second Nuclear Test: Implications of U. N. Security Council Resolution 1874, in North Korea: Nuclear Weapons and the Diplomacy Debate 113 (B.N. Thompson ed., Nova Science 2012).

Paust, Jordan J., Propriety of Self-Defense Targetings of Members of Al Qaeda and Applicable Principles of Distinction and Proportionality, 18(2) ILSA Journal of International \& Comparative LAW 565 (2012).

Rodenhäuser, Tilman, Human Rights Obligations of Non-State Armed Groups in Other Situations of Violence: The Syria Example, 3(2) Journal of International Humanitarian Legal Studies 263290 (2012).

Slager, Katherine, Legality, Legitimacy and Anticipatory Self-Defense: Considering an Israeli Preemptive Strike on Iran's Nuclear Program, 38(1) North Carolina Journal of International Law \& ComMERCiAL REgulation 267 (2012).

Toone, Jordan E., Occupation Law During and After Iraq: The Experience of Conservationism Evidenced in the Minutes and Resolutions of the Iraqi Governing Council, 24(3) Florida Journal of INTERNATIONAL LAW 469 (2012).

\section{INTERNATIONAL CRIMINAL LAW AND TRANSNATIONAL CRIME}

Azarov, V. \& Weill, S., Israel's Unwillingness? The Follow-Up Investigations to the UN Gaza Conflict Report and International Criminal Justice, 12(5) International Criminal Law Review 905 (2012).

Piracy and International Maritime Crimes in ASEAN: Prospects For Cooperation (Robert C. Beckman \& J. Ashley Roach eds., Edward Elgar Publishing 2012).

Bewicke, Aurora E., Cultural Relativism and Asian Participation at the International Criminal Court, 18(2) Australian Journal of HuMAN Rights 139 (2012).

Chang, Lennon Yao-Chung, Cybercrime in the Greater China Region: Regulatory Responses and Crime Prevention Across The Taiwan Strait (Edward Elgar 2012). 
Chi, Manjiao, Finding out the 'Achilles' Heels': Piracy Suppression Under International Law and Chinese Law, 5(1) Journal of East Asia \& INTERNATIONAL LAW 7 (2012).

Davenport, Tara, Legal Measures to Combat Piracy and Armed Robbery in the Horn of Africa and in Southeast Asia: A Comparison, 35 Studies in Conflict And Terrorism 570 (2012).

Forster, Thomas, The Khmer Rouge and the Crime of Genocide: Issues of Genocidal Intent with Regard to the Khmer Rouge Mass Atrocities (Dike 2012).

Ginting, Jamin, Roles of the Mutual Legal Assistances and Extradition Agreements in the Assets Recovery in Indonesia, 9(4) Indonesian Journal of International LAW 565 (2012).

Hood, Anna, Prosecuting International Crimes in Australia: The Cases of the Sri Lankan President, 13(1) Melbourne Journal of InternaTIONAL LAW 235-265 (2012).

Huang, Yao, Universal Jurisdiction over Piracy and East Asian Practice, 11(4) Chinese Journal of International Law 623-655 (2012).

Ikaningtyas (Mrs.) \& Ruslijanto, Patricia Audrey, The ASEAN Way Towards Piracy Challenge, 9(3) Indonesian Journal of International LAW 444 (2012).

Iqbal, M. Putra, International Efforts to Combat Corruption and States' Concern: A Perspective from 4.5 Years Silence of Indonesia-Singapore Extradition Treaty, 9(3) IndONESIAN JOURNAL OF InTERNATIONAL LAW 423 (2012).

Kent, Lia, Interrogating the "Gap" Between Law and Justice: East Timor's Serious Crimes Process, 34(4) Human Rights Quarterly 10211044 (2012).

Kielsgard, Mark D., The Legality Principle in Sentencing at the ECCC: Making Up Law as It Goes Along?, 2(1) Asian Journal of InTERNATIONAL LAW 119-136 (2012).

Kneebone, Susan \& Debeljak, Julie, Transnational Crime and Human Rights: Responses to Human Trafficking in the Greater Mekong Subregion (Routledge 2012). 
Lai, Wen-Wei, Forgiven and Forgotten: The Republic of China in the United Nations War Crimes Commission, 25(2) Columbia Journal of AsIAN LAW 306-368 (2012).

Lee, Eric Yong Joong, Military Rescue Operation for the Hostages Taken by Somali Pirates: Was the Korean Navy's "Daybreak in the Gulf of Aden” Legitimate?, 5(1) Journal of EAst Asia \& International LAw 37 (2012).

Lee, Seokwoo \& Park, Young Kil, International Decision: "Republic of Korea v. Araye”, 106(3) American Journal of InTERnATIONAL LAW 630-636 (2012).

Maskun, The Conceptual Framework of Crimes Against Humanity in Historical Context and Indonesian Law, 2(3) Indonesia Law REview 283 (2012).

Milbrandt, Jay, Tracking Genocide: Persecution of the Karen in Burma, 48(1) Texas International Law Journal 63-101 (2012).

Mylonaki, Emmanquela, Defining Terrorism: The Contribution of the Special Tribunal for Lebanon, 2012 Jura: A Pecsi Tudomanyegyetem Allam- es Jogtudomanyi KaranaK tudomanyos lapja 78 (2012).

Nasser, Salem Hikmat, International Law and Politics: International Criminal Courts and Judgments - The Case of the Special Tribunal for Lebanon, 15(2) Gonzaga Journal of International Law 146 (2012).

Oh, Amanda Mortwedt, A House Divided Against Itself Cannot Stand: The Case for Ending the Extraordinary Chambers in the Courts of Cambodia, 10 University of St. Thomas Law Journal 502 (2012).

Global Anti-Terrorism Law and Policy (Victor V. Ramraj, Michael Hor, Kent Roach \& George Williams eds., Cambridge University Press 2012).

Ratner, Steven R., Accountability and the Sri Lankan Civil War, 106(4) American Journal of International LaW 795 (2012).

Ridley, Nick, Terrorist Financing: The Failure of Counter MeaSURES (Edward Elgar 2012).

Ronen, Yaël, The Use and Abuse of International Law: Choice of Applicable Criminal Law in Post-Conflict East Timor, in International LaW 
in Domestic Courts: Rule of Law Reform in Post-conflict States (Edda Kristjánsdóttir, André Nollkaemper \& Cedric Ryngaert eds., Intersentia 2012).

Ryan, Allan A., Yamashita's Ghost: War Crimes, MacArthur's Justice, and Command Accountability (University Press of Kansas 2012).

Schloenhardt, Andreas, Fighting Organized Crime in the Asia Pacific Region: New Weapons, Lost Wars, 2(1) Asian Journal of InterNATIONAL LAW 137-167 (2012).

Sperfeldt, Christoph, Cambodian Civil Society and the Khmer Rouge Tribunal, 6(1) International Journal of Transitional Justice 149-160 (2102).

Sperfeldt, Christoph, Collective Reparations at the Extraordinary Chambers in the Courts of Cambodia, 12(3) International Criminal Law Review 457-490 (2012).

Vaid, Kaveri, What Counts as 'State Action' Under Article 17 of the Rome Statute? Applying the ICC's Complementarity Test to Non-Criminal Investigations by the United States into War Crimes in Afghanistan, 44(2) New York University Journal of International Law \& Politics 573 (2012).

Wagle, Rishikesh, Judicial Activism and the Use of International Law as Gap-filler in Domestic Law: The Case of Forced Disappearances Committed During the Armed Conflict in Nepal, in International LaW in Domestic Courts: Rule of LaW Reform in Post-conflict States (Edda Kristjánsdóttir, André Nollkaemper \& Cedric Ryngaert eds., Intersentia 2012).

Williams, Sarah, Hybrid and Internationalised Criminal TriBunals: Selected Jurisdictional Issues (Hart Publishing 2012).

Windle, J., Afghanistan, Narcotics and the International Criminal Court: From Port of Spain to Kabul, via Rome, 20(3) European Journal of Crime, Criminal Law \& Criminal Justice 297 (2012).

Witsch, Michael C., Legitimacy on Trial at the Extraordinary Chambers, 26(1) Temple International \& Comparative LaW Journal 143 (2012). 


\section{PEACE AND TRANSITIONAL JUSTICE}

Braithwaite, John, Evaluating the Timor-Leste Peace Operation, 16(3) Journal of International Peacekeeping 282-305 (2012).

Bräuchler, Birgit, Intangible Cultural Heritage and Peace Building in Indonesia and East Timor, in Routledge Handbook of Heritage in Asia (Patrick Daly \& Tim Winter eds., Routledge 2012).

Cain, Geoffrey, How can an Information Campaign Win Support for Peacekeeping? The Case of UNTAC in Cambodia, 1923-93, 16 JournaL of International Peacekeeping 175-197 (2012).

Heng, Yee-Kuang, Confessions of a Small State: Singapore's Evolving Approach to Peace Operations, 16(1) Journal of International PeAcekeeping 119-151 (2012).

Höglund, Kristine \& Orjuela, Camilla, Hybrid Peace Governance and Illiberal Peacebuilding in Sri Lanka, 18(1) Global Governance 89-104 (2012).

Issa, Mohammad Saleh Bani, The Influence of the Palestine Conflict on a Just Comprehensive and Lasting Peace in West Asia, 5(4) Journal of Politics \& Law 185 (2012).

Jeffery, Renée, Amnesty and Accountability: The Price of Peace in Aceh, Indonesia, 6(1) International Journal of Transitional Justice 60-82 (2012).

Johnson, Kirsten et al., From Youth Affected by War to Advocates of Peace, Round Table Discussions with Former Child Combatants from Sudan, Sierra Leone and Cambodia, 16(1) Journal of InTERnational PEACEKEEPING 152-174 (2012).

Kent, Lia, The Dynamics of Transitional Justice: International Models and Local Realities in East Timor (Routledge 2012).

China’s Evolving Approach to Peacekeeping (Marc Lanteigne \& Miwa Hirono eds., Routledge 2012).

Murphy, Ray, Peacekeeping in Lebanon and Civilian Protection, 17(3) Journal of Conflict \& Security Law 373-402 (2012). 
Ramanathapillai, Rajmohan, Past Traumas and Present Suffering: Consequences of Buddhist Narratives in the Sri Lankan Peace Process, 35(4) South Asia: Journal of South Asian Studies 832-857 (2012).

Robins, Simon, Challenging the Therapeutic Ethic: A Victim-Centred Evaluation of Transitional Justice Process in Timor-Leste, 6(1) INternational Journal of Transitional Justice 83-105 (2012).

Saikal, Amin, The UN and Afghanistan: Contentions in Democratization and Statebuilding, 19(2) International Peacekeeping 217-234 (2012).

Spector, Bertram I., Negotiating Anti-Corruption Reforms in Post-Conflict Societies: The Case of Afghanistan, 18(2) Brown Journal of World Affairs 45 (2012).

Suhrke, Astri, Waging War and Building Peace in Afghanistan, 19(4) International Peacekeeping 478-491 (2012).

Nepal in Transition: From People's War to Fragile Peace (Sebastian von Einsiedel, David M. Malone \& Suman Pradhan eds., Cambridge University Press 2012).

Wallis, Joanne, A Liberal-Local Hybrid Peace Project in Action? The Increasing Engagement Between the Local and Liberal in Timor-Leste, 38(4) Review of International Studies 735-761 (2012).

Whalan, Jeni, Evaluating Peace Operations: The Case of Cambodia, 16(3) Journal of International Peacekeeping 226-251 (2012).

Wolman, Andrew, Looking Back While Moving Forward: The Evolution of Truth Commissions in Korea, 14(3) Asian-Pacific LaW \& Policy JOURNAL 27-56 (2013).

\section{SECURITY}

Brewster, David, India as an Asia Pacific Power (Routledge 2012).

Human Security and Climate Change in Southeast Asia: Managing Risk and Resilience (Lorraine Elliott \& Mely Caballero-Anthony eds., Routledge 2012).

Maritime Challenges and Priorities in Asia: Implications for Regional Security (Joshua Ho \& Sam Bateman eds., Routledge 2012). 
Green, James A., India's Status as a Nuclear Weapons Power Under Customary International Law, 24(1) National LAw School of India REVIEW 125 (2012).

India And New Zealand in a Rising Asia: Issues and Perspectives (Man Mohini Kaul \& Shekhar Vibhanshu eds., Pentagon Press 2012).

Kumar, Amit, Maritime History of India: An Overview, 8(1) Maritime AfFAIRs 93-115 (2012).

Malhotra, Aditi, Indo-Vietnam Relations: An Answer to Sino-Pak Partnership?, 8(1) Maritime Affairs 71-92 (2012).

Paul, Joshy M., India-Japan Security Cooperation: A New Era of Partnership in Asia, 8(1) Maritime Affairs 31-50 (2012).

Rani, Sudesh, Indo-US Maritime Cooperation: Challenges and Prospects, 8(2) Maritime Affairs 123-143 (2012).

Rumley, Dennis et al., 'Securing' the Indian Ocean? Competing Regional Security Constructions, 8(1) Journal of THE INDian OCEAN REgION 1-8 (2012).

Singh, Amit, Emerging Trends in India-Myanmar Relations, 8(2) MARItime Affairs 25-47 (2012).

Strategic Asia 2012-13: China’s Military Challenge (Ashley J. Tellis \& Travis Tanner eds., National Bureau of Asian Research 2012).

Voloshin, Georgiy, Kazakhstan and Central Asia Security: Ensuring Regional Stability in the Eurasian Balkans, 36(1) Fletcher Forum of World AfFairs 81 (2012).

\section{ENVIRONMENT}

Ansari, Abdul Haseeb, Rio-Principle 10 and Environment Impact Assessment: A Study with Reference to the Malaysian Practice, 52 Indian JOURNAL OF INTERNATIONAL LAW 27-61 (2012).

Barnidge, Robert P. Jr., The 2008 United States-India Nuclear Co-operation Agreement and the Work of the International Law Commission on International Liability for Injurious Consequences Arising Out of Acts not Prohibited by International Law, 2(1) Asian Journal of INTERNATIONAL LAW 1-19 (2012). 
Conrad, Bjorn, China in Copenhagen: Reconciling the Beijing Climate Revolution and the Copenhagen Climate Obstinacy, 210 China QUARTERLY 435 (2012).

Faure, Michael \& Liu, Jing, The Tsunami of March 2011 and the Subsequent Nuclear Incident at Fukushima: Who Compensates the Victims?, 37(1) William \& Mary Environmental Law and Policy Review 129-218 (2012).

Ghorbi, Darian, There's Something in the Water: The Inadequacy of International Anti-Dumping Laws as Applied to the Fukushima Daiichi Radioactive Water Discharge, 27(2) American University InterNational LaW Review 473 (2012).

Gonzalez, Carmen G., China's Engagement with Latin America: Partnership or Plunder?, in Natural Resources and the Green Economy: Redefining the Challenges for People, States and CorporaTions (Elena Blanco \& Jona Razzaque eds., Martinus Nijhoff 2012).

Haas, Lennon Banks, Saving the Trees One Constitutional Provision at a Time: Judicial Activism and Deforestation in India, 40 Georgia Journal of International \& Comparative LaW 751 (2012).

Henry, Laura S. \& Kim, Jasper \& Lee, Dongho, From Smelter Fumes to Silk Road Winds: Exploring Legal Responses to Transboundary Air Pollution over South Korea, 11(3) Washington University Global Studies Law Review 565-626 (2012).

Ibitz, Armin, The Impediments of Policy Coordination on E-Waste in ASEAN, 9(3) Indonesian Journal of International LaW 398 (2012).

Jeffery, Michael I. \& Zhao, Xiaobo, Developing a National Contaminated Land Liability Scheme in China: The Comprehensive Environmental Response, Compensation, and Liability Act Revisited, 30(4) JournAL of Energy \& Natural Resources Law 423 (2012).

Karim, Md. Saiful \& Vincents, Okechukwu Benjamin \& Rahim, Mia Mahmudur, Legal Activism for Ensuring Environmental Justice, 7 Asian Journal of Comparative LaW 1-44 (2012).

Kgiday, Kishan \& Natarajan, Usha, Fairness and International Environmental Law from Below: Social Movements and Legal Transformation in India, 25(2) Leiden Journal of International LaW 415-441 (2012). 
Koh, Kheng-Lian, Transboundary and Global Environmental Issues: The Role of ASEAN, 1(1) Transnational Environmental LaW 67-82 (2012).

Carbon Pricing, Growth and the Environment (Larry Kreiser et al. eds., Edward Elgar 2012).

La Vina, Antonio G. M. \& De Leon, Alaya M. \& Bueta, Gregorio Rafael P., Legal Responses to the Environmental Impacts of Mining, 86(2) Philippine Law Journal 284 (2012).

Lee, Jae-Gon, Region Reports: C. Korea, 23(1) Yearbook of InternaTIONAL ENVIRONMENTAL LAW 474-483 (2012).

Lim, Michelle, Laws, Institutions and Transboundary Pasture Management in the High Pamir and Pamir-Alai Mountain Ecosystem of Central Asia, Law,8(1) Environment and Development Journal 43-[viii] (2012).

Lin, Jolene, Climate Governance in China: Using the 'Iron Hand', in LoCal Climate Change LaW: Environmental Regulation in Cities AND OTher Localities (Benjamin J. Richardson ed., Edward Elgar 2012).

Lu, Dau-Jye et al., Why They Cannot Work Together: A Study of the CoManagement of Natural Resources with Indigenous People in Taiwan, 25(1) Society \& Natural Resources 105 (2012).

Lyons, Youna, Transboundary Pollution from Offshore Oil and Gas Activities in the Seas of Southeast Asia, in Transboundary Environmental Governance in Inland, Coastal and Marine Areas (Robin Warner \& Simon Marsden eds., Ashgate 2012).

Negi, B.S. \& Chauhan, D.S. \& Todaria, N.P., Administrative and Policy Bottlenecks in Effective Management of Van Panchayats in Uttarakhand, India, 8(1) Law, Environment \& Development Journal 141 (2012).

Olbrei, Erik \& Howes, Stephen, A Very Real and Practical Contribution? Lessons from the Kalimantan Forests and Climate Partnership, 3(2) Climate Law 103-137 (2012).

Osaka, Eri, Corporate Liability, Government Liability, and the Fukushima Nuclear Disaster, 21 Pacific Rim Law \& Policy Journal 433-459 (2012). 
Puthucherril, Tony George, Climate Change, Sea Level Rise and Protecting Displaced Coastal Communities: Possible Solutions, 1(2) Global Journal of Comparative LaW 225-264 (2012).

Roesa, Nellyana, The ASEAN Agreement on Trans-Boundary Pollution in Relation with Indonesia Haze, Compliance in Theory and Practice, 9(3) Indonesian Journal of International LAW 452 (2012).

Sellamuttu, Sonali Senaratna et al., The Ramsar Convention's Wise Use Concept in Theory and Practice: An Inter-Disciplinary Investigation of Practice in Kolleru Lake, India, 15 Journal of International Wildlife LaW \& Policy 228 (2012).

Sharma, Charu, Remedies for Environmental Harm: Dharmic Duty and Tort Liability in India - Is there a Common Ground?, 8(1) MACQUARiE Journal of InTERnATIONAL \& COMPARATIVE ENVIRONMENTAL LAW 48 (2012).

Talaat, Wan Izatul Asma Wan et al., The Existing Legislative, Administrative and Policy Framework for the Mangrove Biodiversity Management \& Conservation in Malaysia, 5(1) Journal of Politics And LAW 180 (2012).

Thuppil, Vivek \& Coss, Richard G., Using Threatening Sounds as a Conservation Tool: Evolutionary Bases for Managing Human-Elephant Conflict in India, 15(2) Journal of International WildLife LaW \& PoliCy 167 (2012).

Wardana, I Gusti Agung Made, A Critical Analysis Of REDD+ Legal Architecture In Reducing Emissions From Forestry Sectors in Indonesia, 2(1) Indonesia LaW Review 75 (2012).

Wibowo, Lukas Rumboko et al., Forest Policy and Legal Pluralism: A Case Study in Luwu District, Indonesia, 2(1) Indonesia Law Review 1 (2012).

\section{ENERGY}

Secure Oil and Alternative Energy: The Geopolitics and Energy Paths of China and the European Union (M. Parvizi Amineh \& Yang Guang eds., Brill 2012).

Nuclear Power and Energy Security in Asia (Rajesh Basrur \& Swee Lean Collin Koh eds., Routledge 2012). 
Blazey, Patricia, Will China's 12th Five Year Plan Allow for Sufficient Nuclear Power to Support its Booming Economy in the Next Twenty Years?, 21 Pacific Rim Law \& Policy Journal 461-484 (2012).

Burns, Stephen G., The Fukushima Daiichi Accident: The International Community Responds, 11 Washington University of Global Studies Law Review 739-780 (2012).

Dorfman, Daniel A., The Changing Perspectives of U.S and Japanese Nuclear Energy Policies in the Aftermath of the Fukushima Daiichi Disaster, 30 Pace Environmental Law Review 255-290 (2012).

Fukurai, Hiroshi, Introduction: The Fukushima Dai-Ichi Nuclear Disaster and the Future of Nuclear Energy Programs in Japan and East Asia, 21 Pacific Rim Law \& Policy Journal 427-432 (2012).

Ghori, Umair, Risky Winds: Investing in Wind Energy Projects in Pakistan, 30(2) Journal of Energy \& Natural Resources LaW 129-158 (2012).

Granit, Jakob et al., Regional Options for Addressing the Water, Energy and Food Nexus in Central Asia and the Aral Sea Basin, 28(3) InTERnational Journal of Water Resources Development 419-432 (2012).

Islam, Shahnila, Implications of Biofuel Policies for Water Management in India, 28(4) International Journal of Water Resources Development 601-613 (2012).

Li, Xinlin, Hydropower in the Mekong River Basin: A Balancing Test, 24(1) Environmental Claims Journal 51-69 (2012).

Walker, Michael J. \& Henry, Elise M., Response to The Changing Perspectives of U.S. and Japanese Nuclear Energy Policies in the Aftermath of the Fukushima Daiichi Disaster (by Daniel A. Dorfman), 30 PACE Environmental LAw Review 291-298 (2012).

Wisuttisak, Pornchai, Liberalization of the Thai Energy Sector: A Consideration of Competition Law and Sectoral Regulation, 5(1) JoURNAL of World Energy LAW \& Business 60-77 (2012)

Yodogawa, Noriko \& Peterson, Alexander M., An Opportunity for Progress: China, Central Asia, and the Energy Charter Treaty, 8(1) Texas Journal of Oil, Gas \& ENERgy Law 111-142 (2012). 


\section{DEVELOPMENT}

Anwar, Arman, Dimensions of ASEAN Cooperation in Health Development of Southeast Asia, 10(1) INDONESIAN JournaL OF INTER ATIONAL LAW 137 (2012).

Balasubramanya, Soumya \& Wichelns, Dennis, Economic Incentives Can Enhance Policy Efforts to Improve Water Quality in Asia, 28(2) International Journal of Water Resources Development 217-231 (2012).

Berlianti, Yeni Salma \& Dewi, Yetty Komalasari, Should National Sharia Board be Restructured to Sustain the Development of Economic Sharia in Indonesia?, 9(4) INDONESIAN JOURNAL OF INTERNATIONAL LAW 583 (2012).

Bezdek, Barbara L., Dreaming in Chinese: Accountable Development, 27 Maryland Journal of International LaW 48-81 (2012).

Chen, Taiyong, Institutional Constraints and Expanding Spaces: A Case Study on Heifer International's Localized Development in China, 4(1) China Nonprofit Review 135-147 (2012).

Dasgupta, Simanti, Rethinking Participation: Water, Development and Democracy in Neo-Liberal Bangalore, Volume 35(3) South Asia: Journal of South Asian Studies 520-545 (2012).

Dharmawan, Ni Ketut Supasti, Tourism and Environment: Toward Promoting Sustainable Development of Tourism: A Human Rights Perspective, 2(1) Indonesia Law Review 23 (2012).

Feng, Lin \& Buhi, Jason, The Constitutional Imperative of Equitably Distributing the Proceeds of Mineral Resource Extraction from China's Ethnic Minority Autonomous Areas, 4(1) Kentucky Journal of Equine, Agriculture and Natural Resources Law 1-30 (2012).

Gathii, James Thuo, Beyond China's Human Rights Exceptionalism in Africa: Leveraging Science, Technology and Engineering for LongTerm Growth, 51 Columbia Journal of Transnational Law 664-688 (2012).

Ge, Zheng, Economic Development and Cultural Autonomy in Tension: The Tibet Issue in China's Constitutional Framework, 42(1) Hong Kong LaW Journal 195-252 (2012). 
Gillespie, John, Exploring the Role of Legitimacy and Identity in Framing Responses to Global Legal Reforms in Socialist Transforming Asia, 29(3) Wisconsin International LAW Journal 534 (2012).

Gillespie, John \& Nicholson, Pip, Law and Development and the Global Discourses of Legal Transfers (Cambridge University Press 2012).

Goswami, Sribas, Health and Child Development Paradox: Findings from Raipur Slums, 9 Indian Journal of Human Rights And THE LAW 129 (2012).

Halydier, Garrett, A Hybrid Legal and Economic Development Model that Balances Intellectual Property Protection and Economic Growth: A Case Study of India, Brazil, Indonesia, and Vietnam, 14(1) AsIAnPacific Law \& Policy Journal 86-151 (2012).

He, Xin, A Tale of Two Chinese Courts: Economic Development and Contract Enforcement, 39(3) Journal of Law AND Society 384 (2012).

Jaiswal, Ajeet, Globalization Impact on Child Health and Nutrition in India, 9 Indian Journal of Human Rights and the Law 115 (2012).

Jarstad, Anna K. \& Olsson, Louise, Hybrid Peace Ownership in Afghanistan: International Perspectives of Who Owns What and When, 18(1) Global Governance 105-119 (2012).

Joshi, Devin K., The Politics of Human Development in India and China: It Pays to Invest in Women and Children, 18(4) LaW \& Business Review of the Americas 487-514 (2012).

Kennedy, Bridget, Why Aid Doesn't Always Equal Development: Sustainable Growth through Aid and APEC in the Asia-Pacific, 37(3) Alternative Law Journal 179-182 (2012).

Lim, Peng Han, Creating a Sustainable Inter-City ASEAN Football League, Regional Television Programming Network, (Content/ IP Industry) Sports Tourism and Travel Industry and Developing Principles for a Legal Framework to Achieve Economic and Socio-Cultural Integration, 10(1) Indonesian Journal of International LaW 45 (2012).

Law and Development in Asia (Gerald Pau McAlinn \& Caslav Pejovic eds., Routledge 2012). 
Olcott, Martha Brill, Tajikistan's Difficult Development Path (Carnegie Endowment for International Peace 2012).

Routh, Supriya, Developing Human Capabilities Through Law: Is Indian Law Failing?, 3(1) Asian Journal of LAW \& Economics 1-22 (2012).

Seth, Binny, Institutionalized Corruption in India: Judicial Systems, Ineffective Mechanisms, and Movements of Reform, 15(2) Touro INTERNATIONAL LAW REVIEW 169 (2012).

Upton, Caroline, Managing Mongolia's Commons: Land Reforms, Social Contexts, and Institutional Change, 25(2) Society \& Natural ReSOURCES 156 (2012).

Woo, Margaret Y., Bounded Legality: China's Developmental State and Civil Dispute Resolution, 27 Maryland Journal of International LAw 235-262 (2012).

\section{HUMAN RIGHTS - GENERAL}

Nationalism and Human Rights: In Theory and Practice in the Middle East, Central Europe, and the Asia-Pacific (Grace Cheng ed., Palgrave Macmillan 2012).

De Silva de Alwis, Rangita, Domestic Violence Lawmaking in Asia: Some Innovative Trends in Feminist Lawmaking, 29(2) PACIFIC BASIN LAW JoURNAL 176-233 (2012).

Duara, Juliette G., Religious Pluralism, Personal Laws and Gender Equality in Asia: Their History of Conflict and the Prospects for Accommodation, 7 Asian Journal of Comparative Law 1-27 (2012).

Le, Uyen P., A Culture of Human Rights in East Asia: Deconstructing Asian Values Claims, 18(2) U.C. Davis Journal of International LaW \& Policy 469-504 (2012).

Monshipouri, Mahmood \& Trapp, Travis, HIV/AIDS, Religion, and $\mathrm{Hu}-$ man Rights: A Comparative Analysis of Bangladesh, Indonesia, and Iran, 13(2) Human Rights Review 187-204 (2012).

Perlin, Michael L., Promoting Social Change in Asia and the Pacific: The Need for a Disability Rights Tribunal to Give Life to the U.N. Convention on the Rights of Persons with Disabilities, 44(1) George Washington International Law Review 1-37 (2012). 
Richards, David L. \& Clay, K. Chad, An Umbrella With Holes: Respect for Non-Derogable Human Rights During Declared States of Emergency, 1996-2004, 13(4) Human Rights Review 443-471 (2012).

Selya, Roger Mark, A Geography of Human Rights Abuses, 34 Human Rights QuARTERLY 1045-1083 (2012).

Smith-Cannoy, Heather, Insincere Commitments: Human Rights Treaties, Abusive States, and Citizen Activism (Georgetown University Press 2012).

Sonipat Declaration, 13(1) Asia-Pacific Journal on Human Rights \& THE LAW 95-99 (2012).

\section{HUMAN RIGHTS - ORGANIZATIONS}

Aguirre, Daniel \& Pietropaoli, Irene, Human Rights Protection the ASEAN Way: Non-Intervention and the Newest Regional Human Rights System, 1(2) International Human Rights Law Review 276-311 (2012).

ASEAN Human Rights Declaration, 13(2) Asia-Pacif IC Journal on HuMAN Rights \& THE LAW 74-81 (2012).

Baek, Buhm-Suk, Medium Foreseeing the Future: The Role of NHRIs in Creating RHRIs in the Asia-Pacific Region, 8(1) Socio-Legal REview 36-112 (2012).

Baek, Buhm-Suk, Mere Ritual or Gradual Change: Why Has Asia Failed to Establish Regional Human Rights Institutions Thus Far?, 5(1) Northwestern Interdisciplinary LaW Review 145-190 (2012).

Baek, Buhm-Suk, RHRIs, NHRIs and Human Rights NGOs, 24(2) FLORIDA JOURNAL OF INTERNATIONAL LAW 235-270 (2012).

Baik, Tae-Ung, Emerging Regional Human Rights Systems in Asia (Cambridge University Press 2012).

Basham-Jones, Deborah, ASEAN's Intergovernmental Commission on Human Rights: A Pale Shadow Of What It Could Have Been, 13(2) Asia-Pacific Journal on Human Rights \& The Law 1-26 (2012).

Conclusions and Recommendations of the 2012 Workshop on Human Rights and Development in ASEAN, 13(1) Asia-PACIFIC JournAL ON Human Rights \& THE LAw 100-102 (2012). 
Outcome of the Bangkok Judicial Colloquium on the Domestic Application of International Human Rights Norms, 13(2) Asia-PACIfIC JournaL ON HuMAN Rights \& THE LAW 85-90 (2012).

Petersen, Carole J., ASEAN and the Convention on the Rights of Persons with Disabilities: Using International Law to Promote Social and Economic Development, 10(1) Indonesian Journal of InTERnATIONAL LAW 1 (2012).

Puspita, Natalia Yeti, Human Rights Protection to Women in Times of Natural Disasters in the Frame of ASEAN Regulations, 10(1) INDONESIAN JOURNAL OF INTERNATIONAL LAW 117 (2012).

Renshaw, Catherine \& Fitzpatrick, Kieren, National Human Rights Institutions in the Asia Pacific Region: Change Agents Under Conditions of Uncertainty, in Human Rights, State Compliance, and Social Change: Assessing National Human Rights Institutions (Ryan Goodman \& Thomas Pegram eds., Cambridge University Press 2012).

Satyawati, Ni Gusti Ayu Dyah, Towards a Common Agreement on Educational Cooperation on Human Rights Education in ASEAN to Promote Human Rights Awareness for the Youth, 10(1) INDONESIAN JOURNAL OF INTERNATIONAL LAW 90 (2012).

Statement of the Asian NGO Network on National Human Rights Institutions on NHRIs and the Right to Development, 13(1) AsIA-PACIFIC Journal on Human Rights \& The Law 91-94 (2012).

\section{HUMAN RIGHTS - CENTRAL ASIA}

Foust, Joshua, Security and Human Rights in Central Asia, 19(1) Brown Journal of World AfFairs 45-58 (2012).

\section{HUMAN RIGHTS - SOUTH ASIA}

Anu \& Kumar, Parmod, Female Foeticide: A Critical Analysis of PNDT Act, 9 Indian Journal of Human Rights \& THe Law 97-113 (2012).

Baset, Zaid Al, Section 377 and the Myth of Heterosexuality, 4(1) JINDAL Global Law Review 89-109 (2012).

Begum, Afroza, Women's Participation in Union Parishads: A Quest for a Compassionate Legal Approach in Bangladesh from an International 
Perspective, 35(3) South Asia: Journal of South Asian Studies 570-595 (2012).

Bochen, Michael \& Knight, Kyle, Establishing a Third Gender Category in Nepal: Process and Prognosis, 26 Emory International LaW REview 11-41 (2012).

Choudhury, Nuara, The Immodest Truth: An Evaluation of the Measures Taken to Combat Sexual Harassment in Bangladesh, 12 BANGLAdESH JOURNAL OF LAW 137-139 (2012).

Deb, Sibnath \& Mathews, Ben, Children's Rights in India: Parents' and Teachers' Attitudes, Knowledge and Perceptions, 20(2) InternaTIONAL Journal of ChILDREN's Rights 241-264 (2012).

Deol, Satnam Singh, Trafficking of Girl Children in India: Magnitude, Causes and Preventive Measures, 9 Indian Journal of Human Rights \& The LAW 203-214 (2012).

Dutta, Aniruddha, Claiming Citizenship, Contesting Civility: The Institutional LGBT Movement and the Regulation of Gender/Sexual Dissidence in West Bengal, India, 4(1) Jindal Global Law Review 100-141 (2012).

Faruque, Abdullah Al, Forensic Use of DNA Information in the Justice Delivery System of Bangladesh: Human Rights and Privacy Challenges, 12 Bangladesh Journal of LAW 1-3 (2012).

Gill, Gitanjali Nain, Human Rights and the Environment in India: Access through Public Interest Litigation, 14(3) Environmental LAW REview 200-218 (2012).

Gopalakrishanan, Bismi, Child Sexual Abuse - An Overview of the Protection of Children from Sexual Offences Act 2012, 9 Indian JourNAL of Human Rights \& The Law 159-169 (2012).

Holladay, Zachary, Public Interest Litigation in India as a Paradigm for Developing Nations, 19(2) Indiana Journal of Global Legal STUdies 555-573 (2012).

Jones, Peris Sean, Powering up the people? The Politics of Indigenous Rights Implementation: International Labour Organisation Convention 169 and Hydroelectric Power in Nepal, 16(4) International Journal of Human Rights 624-647 (2012). 
Kara, Siddharth, Bonded Labor: Tackling the System of Slavery IN South Asia (Columbia University Press 2012).

Khan, Adeeba Aziz, NGOs, the Judiciary and Rights in Bangladesh: Just another Face of Partisan Politics, 1(3) CAMBridge Journal of INTERnATional \& Comparative LAW 254-274 (2012).

Khan, Ashrafuzzaman \& Samadder, Mrinmoy, Weeping of the Forest: Unheard Voices of Garo Adivasi in Bangladesh, 19(3) INTER NATIONAL Journal on Minority And Group Rights 317-326 (2012).

Malagodi, Mara, Constitutional Change and the Quest for Legal Inclusion in Nepal, in Rights in Divided Societies (Colin Harvey \& Alexander Schwartz eds., Hart Publishing 2012).

Mohammed, Furqan, Protecting Pakistani Laborers Post-eighteenth Amendment: Recognizing Rights after the Devolution of Power, 9(2) Loyola University Chicago International Law Review 265-296 (2012).

Murthy, Sharmila L., Land Security and the Challenges of Realizing the Human Right to Water and Sanitation in the Slums of Mumbai, India, 14(2) Health and Human Rights 61-73 (2012).

Narang, Monica, Child Labour and Education of Children in India: An Appraisal, 9(1) Indian Journal of Human Rights \& THE LAw 5-13 (2012).

Challenges to Civil Rights Guarantees in India (Noorani \& South Asia Human Rights Documentation Centre eds., Oxford University Press 2012).

Parven, Khaleda, Forensic Use of DNA Information in the Justice Delivery System of Bangladesh: Human Rights and Privacy Challenges, 12 BANGLADESH JOURNAL OF LAW 73-75 (2012).

Pathi, R. B., Female Feticide in Kolhapur District, India: An Overview, 8 Indian Journal of Human Rights \& Justice 59-74 (2012).

Phookun, Archita \& Pandey, Anupam, Right to Information - A Stone in the Shoe of the Mighty Indian Judiciary, 9 Indian Journal of HuMAN Rights \& THE LAW 215-229 (2012).

Child Marriage in India: Socio-legal and Human Rights DimenSIONs (Jaya Sagade ed., Oxford University Press 2012). 
Saul, Ben, An Experiential International Law Field School in the Sky: Learning Human Rights and Development in the Himalayas, 22(2) Legal Education Review 273-316 (2012).

Shanthakumar, S., Labour and Fundamental Human Rights: Is Equal Remuneration Law Doing the Job It Is Supposed to Do to Eliminate the Gender Pay Gap in India?, 9(2) US-China Law Review 124-130 (2012).

Sharma, Pinki, The Right to Education and Human Rights: National and International Perspectives, with Special Reference to India, 52 IndiaN JOURNAL OF INTERNATIONAL LAW 388-420 (2012).

Singh, Chitwan Deep \& Pranjal, Prashant \& Arora, Sahil, The Protection of Children from the Sexual Offences Act, 2012: A Critique of the Decision to Raise the Age of Consent for Sexual Relations, 3(2) Journal of Indian LaW \& Society 286-301 (2012).

Sinha, Chitra, Debating Patriarchy: The Hindu Code Bill ControVERSY IN INDIA (1941-1956) (Oxford University Press 2012).

Tellis, Ashley, Disrupting the Dinner Table: Re-thinking the 'Queer Movement' in Contemporary India, 4(1) Jindal Global Law Review 142-156 (2012).

Thapliyal, Nisha, Unacknowledged Rights and Unmet Obligations: An Analysis of the 2009 Indian Right to Education Act, 13(1) AsiaPacific Journal on Human Rights \& the Law 65-90 (2012).

Uppaluri, Ujwala \& Shivanagowda, Varsha, Preserving Constitutive Values in the Modern Panopticon: The Case for Legislating toward a Privacy Right in India, 5(1) NUJS Law Review 21-47 (2012).

\section{HUMAN RIGHTS - NORTHEAST ASIA}

Chen, Bo, China's Dilemma in Human Rights: Through the Perspective of Critiques Abroad and China's Response, 5(3) Journal of Politics \& LAW 25-32 (2012).

Chow, Daniel, China and Human Rights in International Trade, 9(1) South Carolina Journal of International LaW \& Business 13-38 (2012).

Cohen, Jane E. \& Amon, Joseph J., Lead Poisoning in China: A Health and Human Rights Crisis, 14(2) Health \& Human Rights 74-86 (2012). 
Dudden, Alexis, Is History a Human Right? Japan and Korea's Troubles with the Past, in The Human Rights Revolution: An InternaTional History (Akira Iriye, Petra Goedde \& William I. Hitchcock eds., Oxford University Press 2012).

High, Anna Jane, China's Orphan Welfare System: Laws, Policies and Filled Gaps, 8(2) East Asia Law Review 127-176 (2012).

Kinzelbach, Katrin, Will China's Rise Lead to a New Normative Order?, 30(3) Netherlands Quarterly of Human Rights 299-332 (2012).

Koo, Jeong-Woo \& Kong, Suk-Ki \& Chung, Chinsung, Measuring National Human Rights: A Reflection on Korean Experiences, 34(4) Human Rights QUARTERLY 986-1020 (2012).

Lee, Man Yee Karen, The Chinese People's struggle for Democracy and China's Long Quest for Dignity, 27(2) Connecticut Journal of INTERNATIONAL LAW 207-242 (2012).

Liu, Chang-Qiu, On Human Experimentation: A Perspective of China's Criminal Law, 3(3) Beijing Law Review 109-111 (2012).

Lo, Vai Io, Promotion of the Employment of Persons with Disabilities in Japan, the United States, and China: Carrot, Stick, or Both, 29 Arizona Journal of International \& Comparative LaW 557-602 (2012).

MacLean, Douglas, Legal Routes to Undue Influence: Vulnerabilities in the Korean National Human Rights Commission Act, 3(2) YonseI LAW Journal 161-190 (2012).

Ng, Yee-Fui, Disability Rights v. Quality Birth Rhetoric: The Construction of Disability in China, (2012) LAWASIA Journal 1 (2012).

Ramsden, Michael, Using the ICESCR in Hong Kong Courts, 42(3) Hong Kong LaW Journal 839-864 (2012).

Rhie, Bryan, O Justice, Where art Thou: The Search for Justice for "Comfort women”, 11 Korea University LaW Review 65-85 (2012).

Sautman, Barry, The Chinese Are the Worst: Human Rights and the Labor Practices in Zambian Mining, 2012(3) Maryland Series in ConTEMPORARY Asian STUdies 1-100 (2012). 
Tokunaga, Emika, The Rights of Disaster Victims: Japan's Triple Disaster Two Years On, 30 Chinese (Taiwan) Yearbook of International LAW \& AFFAIRS 127-142 (2012).

Van Winkle, Andrew B., Separation of Religion and State in Japan: A Pragmatic Interpretation of Articles 20 and 89 of the Japanese Constitution, 21(2) Pacific Rim Law \& Policy Journal 363-398 (2012).

Wagner, Benjamin K. \& VanVolkenburg, Matthew, HIV/AIDS Tests as a Proxy for Racial Discrimination? A Preliminary Investigation of South Korea's Policy of Mandatory In-Country HIV/AIDS Tests for its Foreign English Teachers, 11(2) Journal of Korean Law 179245 (2012).

Wang, Yun Hai, The Death Penalty and Society in East Asia: How to Understand and Compare the Death Penalty in China, Japan and South Korea, 40 Hitotsubashi Journal of Law \& Politics 1-14 (2012).

Webster, Timothy, China's Human Rights Footprint in Africa, 51(3) CoLUMbia Journal of Transnational LAW 626-664 (2012).

Yamamoto, Eric K. \& Lee, Sara, Korean “Comfort Women” Redress 2012 Through the Lens of U.S. Civil and Human Rights Reparatory Justice Experiences, 11(2) Journal of Korean Law 123-149 (2012).

Zang, Dongsheng, China's "Attitude" toward Human Rights: Reading Hungdah Chiu in the Era of the Iraq War, 27(1) MARYLAND JournaL of INTERNATIONAL LAW 263-303 (2012).

Zhang, Haiting, The Laws on the Ethnic Minority Autonomous Regions in China: Legal Norms and Practices, 9(2) Loyola University CHICAgo International LAW Review 249-264 (2012).

Zou, Bing, On the Application of Death Penalty to Elderly Offenders in China, 5(2) Journal of Politics \& LAw 140-144 (2012).

\section{HUMAN RIGHTS - WEST ASIA}

Afshari, Reza, Iran: An Anthropologist Engaging the Human Rights Discourse and Practice, 34(2) Human Rights Quarterly 507-545 (2012).

Alhargan, Raed A., The Impact of the UN Human Rights System and Human Rights INGOs on the Saudi Government with Special Refer- 
ence to the Spiral Model, 16(4) International Journal of Human Rights 598-623 (2012).

Bohlander, Michael, "There is No Compulsion in Religion" - Freedom of Religion, Responsibility to Protect (R2P) and Crimes Against $\mathrm{Hu}$ manity at the Example of the Islamic Blasphemy Laws of Pakistan, 8(1) Journal of Islamic State Practices in International Law 36-66 (2012).

Dubay, Carolyn A., Beyond Critical Mass: A Comparative Perspective on Judicial Design and Gender Equality in Iraq and Afghanistan, 24(1) FLORIDA Journal of International LAW 163-212 (2012).

Eltayeb, Mohamed Saeed M., The Prohibition of Incitement to National, Racial or Religious Hatred: The Case of West Asian Arab Countries, 7(2) Religion \& Human Rights 95-108 (2012).

Gordon, Neve, The Geography and Political Context of Human Rights Education: Israel as a Case Study, 11(3) Journal of Human Rights 384-404 (2012).

Khoury-Kassabri, Mona \& Ben-Harush, Aya, Discipline Methods Within the Israeli Education System: Arab and Jewish teachers' Attitudes, 20(2) International Journal of Children's Rights 265-278 (2012).

Mehr, Ali Babaee \& Daniali, Medhi, Education Right in Security Council Resolution 1737 Against Iran, 9(2) InternationAl Studies JournaL 155 (2012).

Mennie, David, The Role of the International Covenant on Civil and Political Rights in the Israeli-Palestinian Conflict: Should Israel's Obligations Under the Covenant Extend to Gaza and the Other Occupied Palestinian Territories?, 21(2) Transnational Law \& ContempoRARy Problems 511-548 (2012).

O'Connell, Brian, Constitutional Apostasy: The Ambiguities in Islamic Law After the Arab Spring, 11 Northwestern Journal of InterNATional Human Rights 83 (2012).

Qafisheh, Mutaz M., Human Rights Gaps in the Palestinian Criminal System: A United Nations Role?, 16(2) International Journal of Human Rights 358-377 (2012). 
Qafisheh, Mutaz M., The Dilemma of Legislative Reform in Line with International Standards on Gender Equality in the Islamic World: The Case of Palestine, 1(2) International Journal of Legislative Drafting \& LAW ReForm 219-238 (2012).

Rehman, Javaid \& Berry, Stephanie E., Is “Defamation Of Religions” Passé? The United Nations, Organisation of Islamic Cooperation, and Islamic State Practices: Lessons from Pakistan, 44(3) George Washington InTERnATIONAL LAW REview 431 (2012).

Tavassoli, Ovise Hamed \& Tavassoli, Soudeh Hamed, Reviewing Women Circumcision in the World \& Iran, 9(5) US-CHINA LAW Review 406-419 (2012).

\section{HUMAN RIGHTS - SOUTHEAST ASIA}

Alfitri, Legal Reform Project, Access to Justice and Gender Equity in Indonesia, 9(2) InDONESIAN JOURNAL OF INTERNATIONAL LAW 292 (2012).

Ariadno, Melda Kamil, Indonesian Case on Illegal Migrant, 9(2) IndonESiAn Journal of InTERnATIONAL LAW 245 (2012).

Awal, Datin Noor Aziah Mohd, Rights of Children: Future Challenges in Malaysia, 2012 International Survey of FAmily Law 215 (2012).

Ciorciari, John D., Institutionalizing Human Rights in Southeast Asia, 34(3) Human Rights Quarterly 695-725 (2012).

Crouch, Melissa A., Law and Religion in Indonesia: The Constitutional Court and the Blasphemy Law, 7 Asian Journal of Comparative LAW 1-46 (2012).

Cuyvers, Ludo \& De Meyer, Tim, Market-driven Promotion of International Labour Standards in Southeast Asia: The Corporatization of Social Justice, in Private Standards and Global Governance: Economic, Legal and Political Perspectives (Axel Marx et al. eds., Edward Elgar 2012).

De Lang, Niki Esse, The Establishment and Development of the Myanmar National Human Rights Commission and its Conformity with International Standards, 13(1) Asia-Pacific Journal on Human Rights \& THE LAW 1-41 (2012). 
Gomez, James \& Ramcharan, Robin, The Protection of Human Rights in Southeast Asia: Improving the Effectiveness of Civil Society, 13(2) Asia-Pacific Journal on Human Rights \& The Law 27-43 (2012).

Hak, Nora Abdul, Rights of a Wife in the Case of Conversion to Islam Under Family Law in Malaysia, 26(2) Ar ab Law Quarterly 227-239 (2012).

Hamzić, Vanja, Unlearning Human Rights and False Grand Dichotomies: Indonesian Archipelagic Selves Beyond Sexual/Gender Universality, 4(1) Jinndal Global Law Review 157-170 (2012).

Hoang, Van Nghia, Reinterpreting East-Asian Culture and Human Rights: The Case of Traditional Vietnamese Legal Culture, 9(4) InTERnATional Studies Journal 97 (2012).

Huling, Alice, Domestic Workers in Malaysia: Hidden Victims of Abuse and Forced Labor, 44 New York University Journal of InterNAtional LaW \& Politics 629-680 (2012).

Jumamil, Gerard Joseph M., Islamic Conversion as Alternative to Civil Divorce: Addressing Tensions Between Freedom of Religion and the Inviolable Institution of Marriage, 86(4) Philippine LAw JournAL 864-911 (2012).

Limsira, Patthara, Thailand: The United Nations Rules for the Treatment of Women Prisoners and Non-Custodial Measures for Women Offenders (Bangkok Rules), 15(2) Thailand Journal of Law \& Policy (2012) http://www.thailawforum.com/Vol15-Fall-12.html.

Lowes, Sasha, The Legality of Extraterritorial Processing of Asylum Claims: The Judgment of the High Court of Australia in the 'Malaysian Solution’ Case, 12(1) Human Rights Law Review 168-182 (2012).

Montgomery, Heather, Defining Child Trafficking \& Child Prostitution: The Case of Thailand, 9(2) Seattle Journal for Social Justice 775-811 (2012).

Oetomo, Dédé, New Kids on the Block: Human Rights, Sexual Orientation, and Gender Identity in Southeast Asia, 14(2) Asian-Pacific Law \& Policy Journal 118-131 (2012).

Pangilinan, Christian D., The Dispute over Extrajudicial Killings: The Need to Define Extra Judicial Killings as State-Sponsored Acts, 86(4) Philippine Law Journal 811-863 (2012). 
Phan, Hao Duy, A Selective Approach to Establishing a Human Rights Mechanism in Southeast Asia: The Case for a Southeast Asian Court of Human Rights (Martinus Nijhoff 2012).

Prihandono, Iman, Litigating Human Rights-Related Cases Against TNCs in Indonesia, 2012 LAWASIA Jour NAL 113-158 (2012).

Prihandono, Iman, Renegotiating International Investment Agreements to Incorporate Human Rights Provisions for TNCs: An Examination on Indonesia's Bargaining Power, 1st Annual International Conference on Law, Regulation \& Public Policy 22-31 (Global Science and Technology Forum 2012).

Rahman, Noor Aisha Abdul, Muslim Personal Law and Citizens' Rights: The Case of Singapore, 7 Asian Journal of Comparative LaW 1-29 (2012).

Rajah, Jothie, Authoritarian Rule of Law: Legislation, Discourse and Legitimacy in Singapore (Cambridge 2012).

Selby, Don, Patronage, Face, Vulnerability: Articulations of Human Rights in Thailand, 16(2) International Journal of Human Rights 378-400. (2012)

Sunga, Ricardo A. III, Protecting the Children of the Lost, 86(4) PhilipPINE LAW JoURnal 796-810 (2012).

Walsh, Thomas J., The Law of the Family in Cambodia: Assessing Cambodia's Law on the Marriage and Family, 8(2) REgent JournaL of INTERNATIONAL LAW 137-178 (2012).

Williams, David C., Changing Burma From Without: Political Activism Among the Burmese Diaspora, 19(1) Indiana Journal of Global Legal Studies 121-142 (2012).

Zawacki, Benjamin, Defining Myanmar's Rohingya Problem, 20(3) HuMAN Rights BRIEF 18-25 (2012).

\section{NATIONALITY, MIGRATION AND REFUGEES}

Azizi, Sattar \& Hajiazizi, Bijan \& Hassankhani, Razieh, Lineage Influence on Nationality from Islamic Republic of Iran Law View Point, 5(2) Journal of Politics \& LaW 188 (2012). 
Beker, Avi, Narratives and Justice: Population Exchange Instead of the Right to Return, 50 Justice 29 (2012).

Carmel, Sivan, Well-Founded Fear of Persecution: An Analysis of the Status of Jews from Islamic Countries in the Prism of the International Refugee Convention, 50 Justice 34 (2012).

Contested Citizenship in East Asia: Developmental Politics, NaTiOnAl Unity, AND Globalization (Kyung-Sup Chang \& Bryan S. Turner eds., Routledge 2012).

Cheung, Samuel, Migration Control and the Solutions Impasse in South and Southeast Asia: Implications from the Rohingya Experience, 25(1) Journal of Refugee Studies 50-70 (2012).

Chia, Joyce \& Kenny, Susan, The Children of Mae La: Reflections on Regional Refugee Cooperation, 13(2) Melbourne Journal of InterNATIONAL LAW 838-858 (2012).

Chiu, Man-Chung, Un/Controlling Desire, Becoming Others Negotiating Justice in the Hong Kong Milieu of Mainland Pregnant Women Influx, 3(3) Beijing LAw Review 92-102 (2012).

Doocy, Shannon et al., Household Economy and Livelihoods among Iraqi Refugees in Syria, 25(2) Journal of Refugee Studies 82-300 (2012).

Feldman, Ilana, The Challenge of Categories: UNRWA and the Definition of a 'Palestine Refugee', 25(3) Journal of Refugee Studies 387-406 (2012).

Ferraro, Matthew F., Stateless in Shangri-La: Minority Rights, Citizenship, and Belonging in Bhutan, 48(2) STANFOrd Journal of INTERNATIONAL LAW 405-436 (2012).

Labour Migration and Human Trafficking in Southeast Asia: Critical Perspectives (Michele Ford, Lenore Lyons \& Willem van Schendel eds., Routledge 2012).

Foster, Michelle, The Implications of the Failed 'Malaysian Solution': The Australian High Court and Refugee Responsibility Sharing at International Law, 13 Melbourne Journal of International Law 395 (2012). 
Handelman, Sapir, Jewish Identity and Liberal Nationalism for Israel: The Struggle for National Identity in a Pluralistic Society, 9(4) US-CHINA LAW REview 297 (2012).

Innes, Michael A., Framing Militant Sanctuary Practices in Afghanistan and Iraq, 2001-2011, in Sanctuary Practices in International Perspectives: Migration, Citizenship and Social Movements (Randy Lippert \& Sean Rehaag eds., Routledge 2012).

Kagan, Michael, The UN "Surrogate State" and the Foundation of Refugee Policy in the Middle East, 18(2) UC Davis Journal of InternaTIONAL LAW \& Policy 307 (2012).

Transnational Flows and Permissive Polities: Ethnographies of Human Mobilities in Asia (Barak Kalir \& Malini Sur eds., Amsterdam University Press 2012).

Kent, Andrew, Evaluating the Palestinians' Claimed Right of Return, 34(1) University of Pennsylvania Journal of International LaW 149-276 (2012).

Kirtiraj, Dadarao C., Plight of North Indian Migrants: A Case of Human Rights Violation in Pune City in Maharashtra, 9(4) InternationaL Studies Journal 51 (2012).

Meir-Glitzenstein, Esther, Zionist or Refugees: The Historical Aspect of the Uprooting of the Jews from Arab Countries and their Immigration to Israel, 50 JusticE 21 (2012).

Montgomery, Jessica L., The Inheritance of Inequality: Hukou and Related Barriers to Compulsory Education for China’s Migrant Children, 21(3) Pacific Rim Law \& Policy Journal 591-622 (2012).

Paxton, Alec, Finding a Country to Call Home: A Framework for Evaluating Legislation to Reduce Statelessness in Southeast Asia, 21 PACIFIC Rim LaW \& Policy Journal 624-653 (2012).

Peterson, Glen, The Uneven Development of the International Refugee Regime in Postwar Asia: Evidence from China, Hong Kong and Indonesia, 25(3) Journal of Refugee Studies 326-343 (2012).

Pholphirul, Piriya, Labour Migration and the Economic Sustainability in Thailand, 31(3) Journal of Current Southeast Asian Affairs 59-83 (2012). 
Asian Migration Policy: South, Southeast and East Asia (Md. Mizanur Rahman \& AKM Ahsan Ullah eds., Nova 2012).

Robinson, Cabeiri Debergh, Too Much Nationality: Kashmiri Refugees, the South Asian Refugee Regime, and a Refugee State, 1947-1974, 25(3) Journal of Refugee Studies 344-365 (2012).

Shabaneh, Ghassan, Education and Identity: The Role of UNRWA's Education Programmes in the Reconstruction of Palestinian Nationalism, 25(4) Journal of Refugee Studies 491-513 (2012).

Singh, Vinai Kumar, India and Internally Displaced Persons: Current Legal Avenues and New Legal Strategies, 24(3) International JournaL REFUGEE LAW 509-526 (2012).

Wolman, Andrew, North Korean Asylum Seekers and Dual Nationality, 24(4) International Journal of Refugee Law 793-814 (2012).

Wood, Tamara \& McAdam, Jane, Australian Asylum Policy all at Sea: An Analysis of Plaintiff M70/2011 v. Minister for Immigration and Citizenship and the Australia-Malaysia Arrangement, 61(1) InTERNATional \& Comparative Law QuARTERly 274-300 (2012).

\section{COLONIALISM AND SELF DETERMINATION}

Aung-Thwin, Maitrii, Recovering Peasant Politics in Colonial Burma: Orientalism, Rebellion and the Law, 7(2) Journal of Comparative LAW 39-59 (2012).

Craven, Matthew, Colonialism and Domination, in The Oxford HandBook of the History of International Law (Bardo Fassbender, Anne Peters, Simone Peter \& Daniel Högger eds., Oxford University Press 2012).

Mutaqin, Zezen Zaenal, Indonesian Customary Law and European Colonialism: A Comparative Analysis on Adat Law, 15(1) Thailand Journal of LAw \& Policy (2012) http://www.thailawforum.com/ Vol15-Spring-12.html.

Nordin, Rohaida \& Witbrodt, Matthew Albert, Self-Determination of Indigenous Peoples: The Case of the Orang Asli, 20(2) Asia PACIfIC LAW REview 189-210 (2012). 
Rashed, Haifa \& Short, Damien, Genocide and Settler Colonialism: Can a Lemkin-inspired Genocide Perspective Aid Our Understanding of the Palestinian Situation? 16(8) International Journal of Human Rights 1142-1169 (2012).

Ruskola, Teemu, The World According to Orientalism, 7(2) Journal of Comparative Law 1-5 (2012).

Shalhoub-Kevorkian, Nadera, The Grammar of Rights in Colonial Contexts: The Case of Palestinian Women in Israel, 4(1) Middle East LAW \& GovernanCe 106-151 (2012).

Takazawa, Chanaka Jun, The Majoritarian Leaderships Dilemmas in Former Colonial Multiracial Societies: Case Study of Cyprus, Sri Lanka, and Singapore, 16 Journal of International AfFairs 59-61 (2012).

Tan, Carol, On Law and Orientalism, 7(2) Journal of Comparative LAW 5-17 (2012).

Tso, Kevin K.S., Fundamental Political and Constitutional Norms: Hong Kong and Macau Compared, 13(1) Australian Journal of Asian LAW 1-24 (2012).

Vajpeyi, Ananya, Righteous Republic: The Political Foundations of Modern India (Harvard University Press 2012).

\section{INTERNATIONAL ECONOMIC AND BUSINESS LAW - GENERAL}

Abad, Anthony Amunategui, Competition Law and Policy in the Framework of ASEAN, in Competition Policy and Regional Integration in Developing Countries (Josef Drexl et al. eds., Edward Elgar 2012).

Research Handbook on International Banking and Governance (James R. Barth, Chen Lin \& Clas Wihlborg eds., Edward Elgar 2012).

Brown, Joshua, U.S.-China Trade Imbalance: The Economic, Political, and Legal Implications of Chinese Currency Manipulation, 9 BYU International LaW \& Management Review 53 (2012).

Chen, An, On the Source, Essence of "Yellow Peril" Doctrine and its Latest Hegemony "Variant" - The "China Threat" Doctrine: From the Perspective of Historical Mainstream of Sino-Foreign Economic 
Interactions and Their Inherent Jurisprudential Principles, 13(1) Journal of World Investment \& Trade 1-58 (2012).

Cherry, Judith \& Dobson, Hugo, "Seoul-Searching": The 2010 G-20 Seoul Summit, 18(3) Global Governance 363-381 (2012).

Choi, Won-Mog, Mad-Cow Disease and the Politics of International Economic Law: Implications from Korean Experience, 16(1) JournaL OF Korea Trade 49-62 (2012).

Dai, Long, Relevant Market Definition in U.S. Antitrust Law and the Alternatives of China, 45(3) Revue JuRIdiQue Thémis 565 (2012).

Eichner, Andrew W., Battling Cartels in the New Era of Chinese Antitrust, 47(3) Texas International Law Journal 587-616 (2012).

Fishman, Jesse, Microfinance - Is There a Solution? A Survey on the Use of MFIs to Alleviate Poverty in India, 40(4) Denver Journal of International LaW \& Policy 588-619 (2012).

Fujii, Mariko \& Kawai, Masahiro, Lessons from Japan's Banking Crisis - 1991 to 2005, in RESEARCH HANDBOOK ON INTERNATIONAL Financial Regulation (Kern Alexander \& Rahul Dhumale eds., Edward Elgar 2012).

Islam, Md. Rizwanul, Economic Integration in South Asia: ChartING A Legal Roadmap (Martinus Nijhoff 2012).

Lee, Ki Jong, Promoting Convergence of Competition Policies in Northeast Asia: Culture-Competition Correlation and its Implications, in THE Global Limits of Competition Law (Ioannis Lianos \& D. Daniel Sokol eds., Stanford Law Books 2012).

Luu, Huong Ly, Regional Harmonization of Competition Law \& Policy: An ASEAN Approach, 2(2) Asian Journal of International LaW 291-321 (2012).

The Derivative Action in Asia: A Comparative and Functional Approach (Dan W. Puchniak, Harald Baum \& Michael Ewing-Chow eds., Cambridge University Press 2012).

Puig, Gonzalo Villalta \& Al-Khodiry, Amer, The Economic and Monetary Union of the Gulf Cooperation Council, 46(1) Journal of WOrLD TrADE 121-154 (2012). 
Rahman, Mohammad Masudur \& Kim, Chanwahn, Trade and Investment Potential Among BCIM Countries: Prospects for a Dynamic Growth Quadrangle, 11(2) Journal of International Trade Law \& Policy 163-190 (2012).

Rana, Shruti, The Emergence of the New Chinese Banking System: Implications for Global Politics and the Future of Financial Reform, 27 Maryland Journal of International LAw 215-234 (2012).

Schield, Bradley, China's Exchange Rate Manipulation: What Should the United States Do?, 34(2) Houston Journal of International LaW 415 (2012).

Taxation in ASEAN and China: Local Institutions, Regionalism, Global Systems and Economic Development (Nolan Sharkey ed., Routledge 2012).

Takahashi, Yasushi, Legal and Practical Problems Faced by Philippine and Indonesian Nurses in the Nursing Programs Under Japan's Economic Partnership Agreements: Toward Solutions, 7 Asian Journal of WTO \& International Health Law \& Policy 517-545 (2012).

Thanadsillapakul, Lawan, The Harmonization of ASEAN: Competition Laws and Policy from an Economic Integration Perspective, in Competition Policy And Regional Integration In Developing Countries (Josef Drexl et al. eds., Edward Elgar 2012).

Wang, Emily, The Opaque Future of Tax Information Sharing Between the United States and China: An Analysis of Bank Secrecy Laws and the Likelihood of Entrance into a Tax Information Exchange Agreement, 35(2) Hastings International \& Comparative LaW REVIEW 411-428 (2012).

Wang, Qingjun, Foreign Chambers of Commerce in China: Trends, Challenges and Policy Responses, 4(1) China Nonprofit Review 51-69 (2012).

Zhang, Sheng, The Energy Charter Treaty and China: Member or Bystander?, 13(4) Journal of World Investment \& Trade 597-617 (2012). 


\section{WTO AND TRADE}

Bohanes, Jan, United States - Certain Measures Affecting Imports of Poultry from China: The Fascinating Case that Wasn't, 11(2) WorLd Trade Review 307-325 (2012).

Chi, Manjiao, China's Participation in WTO Dispute Settlement Over the Past Decade: Experiences and Impacts, 15(1) Journal of InTERnATIONAL ECONOMIC LAW 29-49 (2012).

Dhar, Biswajit \& Das, Kasturi, How Vulnerable is India's Trade to Possible Border Carbon Adjustments in the EU?, 46(2) Journal of World Trade 249-299 (2012).

Espa, Ilaria, The Appellate Body Approach to the Applicability of Article XX GATT in the Light of China - Raw Materials: A Missed Opportunity? 46(6) Journal of World Trade 1399-1423 (2012).

Fazzone, Patrick B., The Trans-Pacific Partnership - Towards a Free Trade Agreement of Asia-Pacific?, 43 Georgetown Journal of InternaTIONAL LAW 695-743 (2012).

Gao, Henry, Judicial Review of Trade Remedy Determinations in China: An Untested Theoretical Possibility?, 11(1) Chinese Journal of INTERNATIONAL LAW 165-190 (2012).

Gu, Bin, Applicability of GATT Article XX in China - Raw Materials: A Clash Within the WTO Agreement, 15(4) Journal of InternaTIONAL ECONOMIC LAW 1007-1031 (2012)

Hamanaka, Shintaro, Unexpected Usage of Enabling Clause? Proliferation of Bilateral Trade Agreements in Asia, 46(6) Journal of World Trade 1239-1260 (2012).

He, Lingling, China's WTO Participation in Anti-Dumping Disputes (20012011), 7(4) Frontiers of LaW in China 616-643 (2012).

Hernández, Roberto Hernández, Economic Liberalization and Trade Relations Between Mexico and China, 41(1) Journal of Current Chinese Affairs 49-96 (2012).

Holslag, Jonathan, Unravelling Harmony: How Distorted Trade Imperils the Sino-European Partnership, 46(2) Journal of World Trade 439-456 (2012). 
Horng, Der-Chin, Reshaping the EU's FTA Policy in a Globalizing Economy: The Case of the EU-Korea FTA, 46(2) Journal of WorLd TrADE 301-326 (2012).

Hsieh, Pasha L., The Roadmap for a Prospective US-ASEAN FTA: Legal and Geopolitical Considerations, 46(2) Journal of World Trade 367-395 (2012).

Hsu, Shun-Liang, Border Enforcement of Plant Variety Rights: A Comparison Between Japan and Taiwan, 5(1) Journal of EAst Asia AND INTERNATIONAL LAW 143-164 (2012).

$\mathrm{Hu}$, Hiaxiang, The Role of WTO Law in the Construction of the Chinese Legal System, 3(2) Yonsei Law Journal 226 (2012).

Huang, Cui \& Ji, Wenhua, Understanding China’s Recent Active Moves on WTO Litigation: Rising Legalism and/or Reluctant Response?, 46(6) JoURNAL OF WORLD TRADE 1281-1308 (2012).

Huang, Liyue, The Legal Service Market in China: Implementation of China's GATS Commitments and Foreign Legal Services in China, 5 Tsinghua China Law Review 29 (2012).

Iqbal, Badar Alam, Is SAFTA a Myth or Reality?, 13(1) Journal of World InVESTMENT \& TRADE 103-124 (2012).

Islam, M. Rafiqul \& Alam, Shawkat \& Mukhopadhaya, Pundarik, Integrating Trade in Education Services Between Australia and India: Complementarities and Challenges, 11(2) Journal of InternaTiOnal Trade Law \& Policy 133-147 (2012).

Jayagovind, A., Impact of Permanent Sovereignty over Natural Resources on WTO: A Critique of WTO Ruling in China: Exportation of Raw Materials Case, 52 Indian Journal OF InTERnATIONAL LAW 141-151 (2012).

Jebe, Ruth \& Mayer, Don \& Lee, Yong-Shik, China's Export Restrictions of Raw Materials and Rare Earths: A New Balance Between Free Trade and Environmental Protection?, 44(4) George Washington InTERNATIONAL LAW REVIEW 579 (2012).

Johan, Eva, The Protection of Domestic Industry through Safeguards Instrument GATT/WTO and its Implementation on Downstream Steel Industry in Indonesia, 9(4) INDONESIAN JOURNAL OF INTERNATIONAL LAW 617 (2012). 
John, Jeanne Lee, The KORUS FTA on Foreign Law Firms and Attorneys in South Korea - A Contemporary Analysis on Expansion into East Asia, 33(1) Northwestern Journal of International Law \& Business 237-282 (2012).

Kennedy, Matthew, China's role in WTO Dispute Settlement, 11(4) World Trade Review 555-589 (2012).

Khorana, Sangeeta et al., The Battle over the EU's Proposed Humanitarian Trade Preferences for Pakistan: A Case Study in Multifaceted Protectionism, 46(1) Journal of World Trade 33-59 (2012).

Khorana, Sangeeta \& Subramanian, Sujitha, Potential Accession to the WTO Government Procurement Agreement: A Case-Study on India, 15(1) Journal of International Economic LaW 287-309 (2012).

Kim, Jong Bum, The Evolution of Preferential Rules of Origin in ASEAN's RTAs: A Guide to Multilateral Harmonization, 46(6) Journal of World TRAde 1343-1364 (2012).

Kobayashi, Tomohiko, Pinning Down the Circling Concept of Circumvention: A Comprehensive Approach to Anti-Circumvention Disciplines Under the WTO Agreement on Agriculture, 54 Japanese YearbooK of InTERNATIONAL LAW 365-385 (2012).

Kong, Qingjiang, China's Uncharted FTA Strategy, 46(5) Journal of WORLD Trade 1191-1206 (2012).

Lee, Yong-Shik, First WTO Case on Transitional Product-Safeguard Measure Under Section 16 of the Protocol of China's Accession to the WTO: Affirming Discriminatory Safeguard Measure by the WTO?, 46(4) Journal of World Trade 913-936 (2012).

Lewis, Meredith Kolsky, Achieving a Free Trade Area of the Asia-Pacific: Does the TPP Present the Most Attractive Path?, in The TransPacific Partnership: A Quest for a Twenty-first Century Trade Agreement (C. L. Lim, Deborah Kay Elms \& Patrick Low eds., Cambridge University Press 2012).

Lindberg, Lena \& Alvstam, Claes G., The Ambiguous Role of the WTO in Times of Stalled Multilateral Negotiations and Proliferating FTAs in East Asia, 17(1) International Negotiation 163-187 (2012). 
Liu, Han-Wei \& Maughan, John, China's Rare Earths Export Quotas: Out of the China-Raw Materials Gate, But Past the WTO's Finish Line?, 15(4) Journal of International Economic LaW 971-1005 (2012).

Liu, Hua, Comment on the Invocation of Article XX for Violation of Para. 11.3 in China-Raw Materials, 3(4) Beijing Law Review 152-157 (2012).

Mangelsdorf, Axel \& Portugal-Perez, Alberto \& Wilson, John S., Food Standards and Exports: Evidence for China, 11(3) World Trade REVIEW 507-526 (2012).

Mathis, James \& Laurenza, Eugenia, Services and Investment in the EU-South Korea Free-Trade Area: Implications of a New Approach for GATS V Agreements and for Bilateral Investment Treaties, 13(2) Journal of World InVESTMENT \& TrAdE 157-185 (2012).

Mercurio, B. \& Tyagi, M., China's Evolving Role in WTO Dispute Settlement: Acceptance, Consolidation and Activation, 3 European YEARBOOK OF INTERNATIONAL ECONOMIC LAW 89-124 (2012).

Meredith, Michael W., Malaysia's World Trade Organization Challenge to the European Union's Renewable Energy Directive: An Economic Analysis, 21(2) Pacific Rim Law \& Policy Journal 399-426 (2012).

Prusa, Thomas J. \& Vermulst, Edwin, United States - Anti-Dumping Measures on Polyethylene Retail Carrier Bags from Thailand: A Cat in the Bag, 11(2) World Trade Review 257-271 (2012).

Qi, Tong \& Yang, Qiong, A Turning Point of Non-Market Economy: On the Individual Duty Treatment of the WTO in the Fasteners Antidumping Case Between European Communities and China, 7(3) Frontiers of LAw in China 474-491 (2012).

Qi, Tong, China's First Decade Experience in the WTO Dispute Settlement System: Practice and Prospect, 7 Asian Journal of WTO \& International Health LaW \& Policy 143-180 (2012).

Qian, Wenjie, The Dilemma of China as Respondent to Anti-Subsidy Proceedings: A Study of the First EU Anti-Subsidy Investigation Against China, 46(4) Journal of World Trade 961-977 (2012).

Qin, Julia Ya, The Predicament of China's 'WTO-Plus' Obligation to Eliminate Export Duties: A Commentary on the China-Raw Materials Case, 11(2) Chinese Journal of International Law 237-246 (2012). 
Regan, Donald H., United States - Certain Measures Affecting Imports of Poultry from China: The Fascinating Case that Wasn't, 11(2) WorLd Trade Review 273-305 (2012).

Shadikhodjaev, Sherzod, Customs Duty or Internal Charge? Revisiting the Delineation Issue Within Treaty Interpretation in the China - Auto Parts Case, 7 Asian Journal of WTO \& International Health LAW \& POLICY 195-218 (2012).

Soeparna, Intan, The Rights of Private Economic Actors Under the World Trade Organization Agreements in Indonesia, 2(3) Indonesia LAW REviEW 339 (2012).

Widiatedja, Parikesit, Towards Liberalization of Services in ASEAN: Challenges and Opportunities of ASEAN Framework Agreement on Services (AFAS) on Tourism, 10(1) IndONESIAN Journal OF INTERNATIONAL LAW 65 (2012).

Wu, Chien-Huei, A New Landscape in the WTO: Economic Integration Among China, Taiwan, Hong Kong and Macau, 3 Europe An YearBOOK OF INTERNATIONAL ECONOMIC LAW 241-270 (2012).

WTO and the Greater China: Economic Integration and Dispute Resolution (Chien-Huei Wu ed., Martinus Nijhoff 2012).

Wu, Mark, Antidumping in Asia's Emerging Giants, 53(1) HARvard INTERNATIONAL LAW JOURNAL 1-84 (2012).

Yang, Songling, The Contribution of East and Southeast Asia Legal Culture on the Improvement of DSMs in Newly Created FTAs in this Region, 2(2) International Journal of Public Law \& Policy 105-128 (2012).

Yu, Li, WTO and National Cultural Policy: Rethinking China Measures Affecting Trading Rights and Distribution Services for Certain Publications and Audiovisual Entertainment Products, 45(3) RevuE JURIDIQUE ThÉmis 457 (2012).

Yu, Minyou \& Liu, Heng, China's Ten Years in the WTO: Its Performance and New Challenges, 7(3) Frontiers of Law in China 329-376 (2012).

Zhang, Liying \& Hu, Xiaoyu, Liberalization of Trade and Domestic Control on Cultural Products: The Application of Public Morals Exception in China - Audiovisual Services, 45(3) Revue juridique Thémis 403 (2012). 
Zhou, Weifeng \& Cuyvers, Ludo, The Effectiveness of EU's Generalised System of Preferences: Evidence from ASEAN countries, 11(1) JournaL of International Trade LaW \& Policy 65-81 (2012).

\section{INVESTMENT}

Adhikary, Bishnu Kumar, Trends and Dimensions of FDI in South Asian Economies - A Comparative Analysis, 13(5) Journal of World InVestment \& Trade 729-768 (2012).

Anwar, Syed Tariq, FDI Regimes, Investment Screening Process, and Institutional Frameworks: China versus Others in Global Business, 46(2) Journal of World Trade 213-248 (2012).

Badawy, Tarey, The General Principles of Islamic Law as the Law Governing Investment Disputes in the Middle East, 29(3) Journal of International Arbitration 255-267 (2012).

Foreign Investment and Dispute Resolution Law and Practice in Asia (Vivienne Bath \& Luke Nottage eds., Routledge 2012).

Cai, Lei, Where does China Stand: The Evolving National Treatment Standard in BITs?, 13(3) Journal of World Investment \& Trade 373-389 (2012).

Chaisse, Julien, The Regulation of Trade-Distorting Restrictions in Foreign Investment Law: An Investigation of China's TRIMs Compliance, 3 European Yearbook of International ECONOMIC LAW 159-188 (2012).

Ewing-Chow, Michael \& Fischer, Geraldine R., ASEAN International Investment Agreements: The Incorporation of Global Regulatory Governance, in Global Administrative Law: The Casebook 235-242 (Sabino Cassese, et al., eds., Institute for Int'l Law \& Justice, NYU School of Law 3rd ed. 2012).

Ghouri, Ahmad Ali \& Mahmood, Nida, Deciphering Pakistan's Foreign Investment Policy: A Review of Pakistani BITs, 13(5) Journal of World InVEstment \& Trade 812-873 (2012).

Han, Xiuli, The Case of Philip Morris v. Uruguay: A Preliminary Observation from a Chinese Scholar, 13(5) JournaL OF WORLD INVESTMENT \& TRAde 769-794 (2012). 
Huang, Jie, Negotiating the First Bilateral Investment Agreement Between Mainland China and Taiwan: Difficulties and Solutions, 42(3) Hong Kong LaW Journal 971-1000 (2012).

Iqbal, Badar Alam \& Hassan, Munir \& Rawat, Bhawana, FDI in Retail Sector in South Asia: A Case of India, 13(6) Journal of World InVESTMENT \& TrAde 951-971 (2012).

Kong, Qingjiang, U.S.-China Bilateral Investment Treaty Negotiations: Context, Focus, and Implications, 7 Asian Journal of WTO \& International Health LaW \& Policy 181-194 (2012).

Kuhn, Maximilian \& Jannatifar, Mohammadjavad, Foreign Direct Investment Mechanisms and Review of Iran's Buy-Back Contracts, 5(3) Journal of World ENERgy LaW Business 207-234 (2012).

Investment Treaty Arbitration and International Law Vol. 4 203-219 (Ian A. Laird \& Todd J. Weiler eds., JurisNet 2012).

Liu, Qiao \& Ren, Xiang, Transfer of Funds in China-US BIT Negotiations: Comparing the Articles of Agreement of the IMF, 11(1) Journal of International Trade LaW \& Policy 6-26 (2012).

Mah, Jai S. \& Noh, Sunyoung, A Comparative Analysis of the Patterns of Japanese and Korean Foreign Direct Investment in China, 13(2) Journal of World Investment \& Trade 309-324 (2012).

Mancuso, Salvatore, China in Africa and the Law, 18(1) Annual Survey of International \& Comparative LaW 243 (2012).

Ogawa, Hiroyuki, Effective Enforcement for Investor Protection: Injunction Under the Japanese and the U.S. Securities Regulations, 40 Hiтотsubashi Journal of LaW \& Politics 33 (2012).

Pekkanen, Saadia, Investment Regionalism in Asia: New Directions in Law and Policy?, 11(1) World Trade Review 119-154 (2012).

Qi, Huan, Investment Law in the China-ASEAN Free Trade Agreement, 5(2) Journal of East Asia and International Law 343 (2012).

Qi, Huan, The Definition of Investment and its Development: For the Reference of the Future BIT Between China and Canada, 45(3) Revue JURIDIQUe THÉMIS 541 (2012). 
Ranjian, Prabhash, Non-Precluded Measures in Indian International Investment Agreements and India's Regulatory Power as a Host Nation, 2(1) Asian Journal of International Law 21-58 (2012).

Rawat, Bhawana \& Ahmad, Shakeel, Foreign Direct Investment in India's Service Sector: A Case of Education Sector, 13(2) Journal OF WORLD InVESTMENT \& TRADE 294-308 (2012).

Saha, Souvik CFIUS Now Made in China: Dueling National Security Review Frameworks as a Countermeasure to Economic Espionage in the Age of Globalization, 33 North WESTERn Journal Of INTERNATIONAL LAW \& Business 199 (2012).

Sahoo, Pravakar, Determinants of FDI in South Asia: Role of Infrastructure, Trade Openness and Reforms, 13(2) Journal of World Investment \& TRADE 256-278 (2012).

Sanan, Manu, The White Industries Award - Shades of Grey, 13(4) Journal of World Investment \& Trade 661-686 (2012).

The Legal Protection of Foreign Investment: A Comparative Study (Wenhua Shan ed., Hart Publishing 2012).

Shan, Wenhua \& Gallagher, Norah \& Zhang, Sheng, National Treatment for Foreign Investment in China: A Changing Landscape, 27(1) ICSID Review 120-144 (2012).

Shen, Wei, Dark Past, Grey Present or Bright Future? - Foreign Investors' Access to China's Telecommunications Industry and a Political Economy Analysis of Recent Industrial Policy Moves, 13(4) JournaL of World InVestment \& Trade 513-541 (2012).

Weeramantry, J. Romesh, Investor-State Dispute Settlement Provisions in China's Investment Treaties, 27(1) ICSID Review 192-206 (2012).

\section{INTELLECTUAL PROPERTY}

Agitha, T. G., International Norms for Compulsory Licensing and the Indian Copyright Law, 15 Journal of World Intellectual PropERTY 26-50 (2012).

Birnhack, Michael D., Colonial Copyright: Intellectual Property in Mandate Palestine (Oxford University Press 2012). 
Boumil III, S. James, China's Indigenous Innovation Policies Under the TRIPS and GPA Agreements and Alternatives for Promoting Economic Growth, 12(2) Chicago Journal of International LaW 755-781 (2012).

Cheng, Thomas K., The Patent-Competition Interface in Asia: A Regional Approach?, in Research Handbook On International CompetiTION LAw (Ariel Ezrachi ed., Edward Elgar 2012).

Chow, Daniel, Lessons from Pfizer's Disputes over Its Viagra Trademark in China, 27 Maryland Journal of International Law 82-110 (2012).

Forman, Lisa, From TRIPS-Plus to Rights-Plus: Exploring Right to Health Impact Assessment of Trade-Related Intellectual Property Rights through the Thai Experience, 7 Asian Journal of WTO \& InTERnational Health Law \& Policy 347-375 (2012).

Guo, Meirong, Japanese New Patent Law: Lessons for China, 3(3) Beijing LAW REview 133-136 (2012).

Jaafari, Deema S., Pharmaceutical Patents in Jordan, 15 JournAL OF WORLD Intellectual Property 239-250 (2012).

Johnson, Vinitha, Desperate Times Call For Desperate Measures? Contrasting Thailand and India with Respect to Circumvention of TRIPS (In) Flexibilities in the Access to Medicines Campaign, 15(2) Thailand Journal of LAw And Policy (2012) http://www.thailawforum.com/ Vol15-Fall-12.html.

Kanniah, Rajeswari \& Antons, Christoph, Plant Variety Protection and Traditional Agricultural Knowledge in Southeast Asia, 13(1) AusTralian Journal of Asian LAW 1-23 (2012).

The Law of Reputation and Brands in the Asia Pacific (Andrew T. Kenyon, Megan Richardson \& Wee Loon Ng-Loy eds., Cambridge University Press 2012).

King, Patrick E. \& Lau, Timothy T. \& Kene, Gautam V., Navigating the Shoals of Joint Infringement, Indirect Infringement, and Territoriality Doctrines: A Comparative Analysis of Chinese and American Patent Laws, 25(2) Columbia Journal of Asian Law 275-305 (2012). 
Lee, Nari \& Norrgard, Marcus, Alternatives to Litigation in IP Disputes in Asia and in Finland, 43(1) California Western International LAW Journal 109 (2012).

Lertdhamtewe, Pawarit, Thailand's Plant Protection Regime: A Case Study in Implementing TRIPS, 7(3) Journal of Intellectual Property LAW \& PraCtice 186-193 (2012).

Liu, Yinliang, Justification of the Criminal and Administrative Enforcement of Intellectual Property Rights in China: Historical Contexts and Contemporary Scenes, 3 Peking University Journal of LegAL STUdies 189-211 (2012).

Lusita (Mrs.), Counterfeiting in China: A Great Challenge in Intellectual Property Protection, 9(2) Indonesian Journal of INTERnATIONAL LAW 326 (2012).

Ma, Zhongfa \& Zhang, Yan, TRIPs Agreement and Enforcement of the Intellectual Property Rights in China, 5(2) Journal of EAst Asia \& INTERNATIONAL LAW 407 (2012).

Maguire, Jennifer Wai-Shing, Progressive IP Reform in the Middle Kingdom: An Overview of the Past, Present, and Future of Chinese Intellectual Property Law, 46(3) International LAwyer 893 (2012).

Marsoof, Althaf, TRIPS Compatibility of Sri Lankan Trademark Law, 15 Journal of World Intellectual Property 51-72 (2012).

Michels, Lucas S., A Blueprint for International TRIPS Plus Geographical Indication Protections - An Analysis of Geographical Indication Protection Proposals in the European Union - India Bilateral Trade and Investment Agreement, 15(2) Gonzaga Journal of InTERnATIONAL LAW 113 (2012).

Noerhadi, Cita Citrawinda, Approaches to Trademark Infringement in ASEAN Countries: Analysis of How the Case is Likely to be Decided in Indonesia, 9(2) Indonesian Journal of International LAW 201 (2012).

Payumo, Jane \& Grimes, Howard \& Wandschneider, Philip, Status of National Intellectual Property Rights (IPRs) Systems and its Impact to Agricultural Development: A Time Series Cross Section Data Analysis of TRIPS Member-Countries, 5(1) International Journal of Intellectual Property Management 82-99 (2012). 
Perles, Joshua K., Becoming the Goose that Lays Golden Eggs: Protecting U.S. Intellectual Property in China Through Chinese Investment in the United States, 45 NYU Journal of International Law \& Politics 259-289 (2012).

Qu, Difan \& Li, Yahong, The Challenges for the Enforcement Against Copyright Violations in China Under the TRIPS Agreement, 7(2) Frontiers of LaW in China 244-268 (2012).

Ross, Jason, Licensing and Access Problems Producers of Video Games Face in Foreign Markets: A Case Study, 35(2) Hastings International \& Comparative Law Review 429-450 (2012).

Sardjono, Agus, Culture and Intellectual Property Development in Indonesia, 10(1) Indonesian Journal of International LaW 23 (2012).

Shah, Arjun, Is Bollywood Unlawfully Copying Hollywood? Why? What has Been Done About It? And How Can It Be Stopped?, 26 EmOry International LaW Review 449-487 (2012).

The Future of the Patent System (Ryo Shimanami ed., Edward Elgar 2012).

Spencer, Devon, Not in It for the Long Run: China's Solution for Compliance with TRIPS Requires More than a Nine-Month Campaign, 19(2) University of Miami International \& Comparative Law REVIEW 197-242 (2012).

Suwan-in, Nattapong, Compulsory License, a Long Debate on TRIPS Agreement Interpretation: Discovering the Truth of Thailand's Imposition on Pharmaceutical Patents, 7 Asian Journal of WTO \& International Health LaW \& Policy 225-261 (2012).

Tian, Dexin \& Chao, Chin-Chung, Intellectual Property Rights (IPR) Disputes in Cyberspace: U.S. Hegemony and Chinese Resistance, 5(2) Journal of Politics and LaW 1 (2012).

Washburn, Taylor, Getting Copyright Right in the Trans-Pacific Partnership, 7(1) Yale Journal of International Affairs 117-118 (2012).

Wechsler, A., China's WTO Accession Revisited: Achievements and Challenges in Chinese Intellectual Property Law Reform, 3 European Yearbook of International ECONOMiC 125-159 (2012). 
Wickramasinghe, Chaminda Nalaka \& Ahmad, Nobaya, Influence of Demographic and Technical Profile on Success of Independent Inventors in Sri Lanka, 15 Journal of World Intellectual Property 365-378 (2012).

Williamson, Myra E.J.B., Geographical Indications, Biodiversity and Traditional Knowledge: Obligations and Opportunities for the Kingdom of Saudi Arabia, 26(1) Arab Law Quarterly 99-119 (2012).

Xue, Hong, A User-Unfriendly Draft: 3rd Revision of the Chinese Copyright Law, 7(4) Journal of International Commercial LaW \& Technology 350 (2012).

Yu, Peter K., Shaping Chinese Criminal Enforcement Norms through the TRIPS Agreement, in Criminal Enforcement Of Intellectual Property: A Handbook of Contemporary Research (Christophe Geiger ed., Eward Elgar 2012).

\section{CULTURAL PROPERTY AND HERITAGE}

Aragon, Lorraine V., Copyrighting Culture for the Nation? Intangible Property Nationalism and the Regional Arts of Indonesia, 19(3) International Journal of Cultural Property 269-312 (2012).

Kumar, Dinesh, Protection of Cultural Rights Under the Indian Constitution: An Analysis, 9(4) International Studies Journal 1-35 (2012).

Li, Luo, Does Intangible Cultural Heritage Law Resolve Everything in China?, 7(4) Journal of International Commercial Law \& Technology 355 (2012).

Lloyd, Georgina, Legislating to Safeguard Asia's Intangible Cultural Heritage, in Routledge Handbook of Heritage in Asia (Patrick Daly \& Tim Winter eds., Routledge 2012).

Luo, Guoqiang, International Legal Issues on China's Recourse for Cultural Relics Pillaged Overseas, 7(3) Frontiers of Law in China 454-473 (2012).

Naeem, Anila, ICOMOS Thailand International Conference: Asian Urban Heritage Phuket, Thailand 15-17 October 2011, 19(4) InTERnATIONAL Journal of Cultural Property 543-544 (2012). 
Van Woudenberg, Nout, State Immunity and Cultural Objects on LOAN (Martinus Nijhoff 2012).

Vanguardia, Maria Ester, Dreams for Sale: Traditional Cultural Expressions

(TCEs) and Intellectual Property Rights of the Indigenous Pragmatic Group as Exemplified by the Dreamweavers, 86(2) Philippine LAw JOURNAL 405-[i] (2012).

Wolfgram, Matthew, The Entextualization of Ayurveda as Intellectual Property, 19(3) International Journal of Cultural Property 313-343 (2012).

\section{DISPUTE SETTLEMENT}

Barnett, Michelle, Cambodia v. Thailand: A Case Study on the Use of Provisional Measures to Protect Human Rights in International Border Disputes, 38(1) BrookLyn Journal of InTERNATIONAL LAW 269-304 (2012).

Burch, Micah \& Nottage, Luke \& Williams, Brett, Appropriate TreatyBased Dispute Resolution for Asia-Pacific Commerce in the 21st Century, 35(3) University of New South Wales Law Journal 1013-1044 (2012).

Singh, Sukhsimranjit, Beyond Foreign Policy: A Fresh Look at Cross-Cultural Negotiations and Dispute Resolution Based on the India-United States Nuclear Test Ban Negotiations, 14(1) Cardozo Journal of Conflict Resolution 105-152 (2012).

Tomonori, Mizushima, The Settlement of a Private Person's Claim Against a Foreign "State": The Case of Japan's Foreign State Immunity Act, 30 Chinese (Tainan) Yearbook of International Law and AfFAIRS 31-47 (2012).

\section{ARBITRATION}

Aglionby, Andrew, Notable Characteristics of Arbitration in China, in Contemporary Issues in International Arbitration and Mediation: The Fordham Papers (2011) (Arthur W. Rovine ed., Martinus Nijhoff 2012).

Ahn, Keon-Hyung \& Gallo, Robert \& Oh, Won-Suk, Seoul: A Crossroad for Arbitration Between the Middle East and East Asia, 4(2) InTERnational Journal of Arab Arbitration 47 (2012). 
Al-Hejailan, Salah, The New Saudi Arbitration Act: A Comprehensive and Article-by-Article Review, 4(3) International Journal of Arab Arbitration 15 (2012).

Al-Hoshan, Mohammad, The New Saudi Law on Arbitration: Presentation and Commentary, 4(3) International Journal of Arab ArbitraTION 5 (2012).

Ali, Shahla \& Huang, Hui, Financial Dispute Resolution in China: Arbitration or Court Litigation?, 28(1) Arbitration International 77-100 (2012).

Ali, Shahla F. \& Da Roza, Antonio, Alternative Dispute Resolution Design in Financial Markets - Some More Equal than Others: Hong Kong's Proposed Financial Dispute Resolution Center in the Context of the Experience in the United Kingdom, United States, Australia, and Singapore, 21 Pacific Rim Law \& Policy Journal 485-532 (2012).

Alnowaiser, Khali, The New Arbitration Law and its Impact on Investment in Saudi Arabia, 29(6) Journal of International Arbitration 723-725 (2012).

Arya, Garima Budhiraja \& Sebastian, Tania, Critical Appraisal of 'Patent Illegaility' as a Ground for Setting Aside an Arbitral Award in India, 24(2) Bond Law Review 157 (2012).

Autea, Arthur P., Emerging Legal Trends and Practices in Commercial Arbitration in the Philippines, 86(2) Philippine Law Journal 272283 (2012).

Baskaran, Thayananthan, Recent Amendments to the Malaysian Arbitration Act, 28(3) Arbitration International 533-544 (2012).

Fan, Kun, The Risks of Apparent Bias when an Arbitrator Acts as a Mediator - Remarks on Hong Kong Court's Decision in Gao Haiyan, 13 Yearbook of Private International Law 535 (2011) (Sellier European Law 2012).

Fan, Kun, The New Arbitration Ordinance in Hong Kong, 29(6) JournaL of International Arbitration 715-722 (2012).

Fei, Lan-fang, A Case Study of the Reporting Mechanism of International Arbitration in China, 5(1) Contemporary Asia Arbitration JOURNAL 83-106 (2012). 
Giaretta, Ben, Duties of Arbitrators and Emergency Arbitrators Under the SIAC Rules, 8(2) Asian International Arbitration Journal 196-221 (2012).

Hwang, Michael S.C. \& Thio, Nicholas, A Contextual Approach to the Obligation of Confidentiality in Arbitration in Singapore: An Analysis of the Decision of the Singapore High Court in AAY and Others v. AAZ, 28(2) Arbitration International 225-242 (2012).

Junita, Fifi, Judicial Review of International Arbitral Awards on the Public Policy Exception in Indonesia, 29(4) Journal of International Arbitration 405-427 (2012).

Kim, Joongi, A Pivot to Asia in Investor-State Arbitration: The Coming Emergence of Asian Claimants, 27(2) ICSID REview 399-415 (2012).

Lin, Yifei, Judicial Review of Arbitration Agreements in China, 28(2) ARBITRATION INTERNATIONAL 243-294 (2012).

Lu, Song, The New CIETAC Arbitration Rules of 2012, 29(3) Journal of International Arbitration 299-322 (2012).

Market, Lars, Arbitration Under China's Investment Treaties - Does It Really Work?, 5(2) Contemporary Asia Arbitration Journal 205-241 (2012).

Mohtashami, Reza \& Lawry-White, Merryl, The (Non)-Application of the New York Convention by the Qatari Courts: ITIIC v. Dyncorp, 29(4) Journal of International Arbitration 429-436 (2012).

Moody, Zia \& Jayasimha, Shreyas, Recent Indian Developments Relating to International Arbitration, in CONTEMPORARY IsSues IN INTERnational Arbitration and Mediation: The Fordham Papers (2011) (Arthur W. Rovine ed., Martinus Nijhoff 2012).

Nottage, Luke \& Weeramantry, J. Romesh, Investment Arbitration in Asia: Five Perspectives on Law and Practice, 28(1) Arbitration InterNATIONAL 19-62 (2012).

Pryles, Michael, Recent Singapore Decisions on International Arbitration, 24(1) National Law School of India Review 35 (2012).

Qi, Tong, How Exactly Does China Consent to Investor-State Arbitration: On the First ICSID Case Against China, 5(2) Contemporary Asia Arbitration Journal 265-291 (2012). 
Rai, Sumit, Proposed Amendments to the Indian Arbitration Act: A Fraction of the Whole?, 3(1) Journal of International Dispute Settlement 169-204 (2012).

Ray, Ashutosh, Year 2012: Harbinger of Change for Indian Arbitration?, 29(3) Journal of International Arbitration 345-354 (2012).

Sharma, Ayush, Setting Aside Arbitral Awards - Conflicting Time Limits in India, 8(2) Asian International Arbitration Journal 178-195 (2012).

Simões, Fernando Dias, Macau: A Seat for Sino-Lusophone Commercial Arbitration, 29(4) Journal of International Arbitration 375389 (2012).

Tao, Jingzhou, Salient Issues in Arbitration in China Center, 27(4) AmeriCan University International Law Review 807 (2012).

Thadikkaran, Manu, Judicial Intervention in International Commercial Arbitration: Implications and Recent Developments from the Indian Perspective, 29(6) Journal of International Arbitration 681690 (2012).

Thilak, Jithees, Extension of Jurisdiction of DIFC Courts and its Impact on Arbitration in the Middle East, 8(2) Asian International ArBITRATION JOURNAL 161-177 (2012).

Yang, Honglei \& Wang, Yuan, Mutual Enforcement of Mainland China and the Hong Kong SAR Awards: An Issue of Nationality, 8(1) AsIAN International Arbitration Journal 120-130 (2012).

Yeoh, Friven \& Ang, Desmond, Reflections on Gao Haiyan - of 'Arb-Med', 'Waivers', and Cultural Contextualisation of Public Policy Arguments, 29(3) Journal of International Arbitration 285-297 (2012).

\section{PRIVATE INTERNATIONAL LAW}

Alaoudh, Abdullah S., The Notice Requirement of Article 39 and Islamic Law: Developed vs. Developing Countries, 26(4) Ara b Law QuarTERLY 481-498 (2012).

Al-Masadeh, Nael, The Possibility of Applying the United Nations Convention on Contracts for the International Sale of Goods by a Jordanian Judge, 26(3) Arab Law Quarterly 381 (2012). 
Business Law in Japan - Cases and Comments: Intellectual Property, Civil, Commercial and International Private Law (Moritz Bälz et al. eds., Kluwer Law International 2012).

Chen, Chun-I, Legal Aspects of Mutual Non-Denial and the Relations Across the Taiwan Straits, 27 Maryland Journal of InternaTIONAL LAW 111-127 (2012).

Towards a Chinese Civil Code: Comparative and Historical Perspectives (Lei Chen \& C.H. Rhee (Remco) eds., Martinus Nijhoff 2012).

Chung, Erin Aeran \& Kim, Daisy, Citizenship and Marriage in a Globalizing World: Multicultural Families and Monocultural Nationality Laws in Korea and Japan, 19(1) Indiana Journal of Global Legal Studies 195-219 (2012).

Ebrahimi, Seyed N., An Overview of the Private International Law of Iran: Theory and Practice (Part Two), 13 Yearbook of Private InternaTIONAL LAw 413 (2011) (Sellier European Law 2012).

Einhorn, Talia, Private International Law in Israel (Kluwer Law International 2d ed. 2012).

Friedman, Sara L., Adjudicating the Intersection of Marital Immigration, Domestic Violence, and Spousal Murder: China-Taiwan Marriages and Competing Legal Domains, 19(1) Indiana Journal of Global LEgAL STUdiEs 221-255 (2012).

Guo, Yujun, Changing Private International Law in China, 55 JAPANESE YeARbooK of International LAW 440-455 (2012).

Huo, Zhengxin, Highlights of China's New Private International Law Act: From the Perspective of Comparative Law, 45(3) Revue JURIDIQUE THÉmis 637 (2012).

Huo, Zhengxin, Reshaping Private International Law in China: The Statutory Reform of Tort Conflicts, 5(1) Journal of EAST AsIA \& INTERNATIONAL LAW 93-116 (2012).

Kusrin, Zuliza Mohd et al., Conversion and the Conflict of Laws in Respect of Spouse Rights to Inheritance in Malaysia, 7(1) RELIGION \& HUMAN Rights 1-9 (2012). 
Lee, Jaemin, A Clash Between IT Giants and the Changing Face of International Law: The Samsung vs. Apple Litigation and its Jurisdictional Implications, 5(1) Journal of East Asia \& International LaW 117-142 (2012).

Leeds, Jonathan W., Prenuptial Agreements: US Law, Thailand Law and EU Law Compared, 15(2) Thailand Journal of LaW \& Policy (2012) (2012), http://www.thailawforum.com/Vol15-Fall-12.html.

Liang, Jieying, Statutory Restrictions on Party Autonomy in China's Private International Law of Contract: How Far does the 2010 Codification Go?, 8(1) Journal of Private International LaW 77-112 (2012).

Okuda, Yasuhiro, New Provisions on International Jurisdiction of Japanese Courts, in 13 Yearbook of Private International Law 397 (2011) (Sellier European Law 2012).

Reynolds, Megan J., It Can be Done: On Japan Becoming a Successful Signatory to the Hague Convention on the Civil Aspects of International Child Abduction, 44(2) George Washington International LaW Review 367 (2012).

Rotem, Yaad, Substance versus Procedure in the Conflict of Laws: Israel as a Case Study, 22(1) Journal of Transnational Law \& Policy 1 (2012).

Tang, Zheng Sophia, International Treaties in Chinese Private International Law, 42(2) Hong Kong Law Journal 597-632 (2012).

$\mathrm{Tu}$, Guangjian, Recognition and Enforcement of Non-Local Judgments in Macau: A Critical Review, 42(2) Hong Kong Law Journal 633-660 (2012).

Wu, Yiming, Latest Developments of Private International Law in China, 2012 Jura: A Pecsi Tudomanyegyetem Allam- es Jogtudomany KARANAK TUDOMANYOS LAPJA 217 (2012).

$\mathrm{Wu}$, Yueyao, Construction of a System of Reciprocal Recognition of Civil Case Jurisdiction among China, Japan and ROK, 3 Beijing LaW Review 51-55 (2012).

Zhang, Meirong, Application of Private International Law Conventions in Hong Kong of China, 7(3) Frontiers of Law in China 377-401 (2012). 


\section{INTERNET, DATA AND COMMUNICATIONS}

Abraham, Sunil \& Hickok, Elonnai, Government Access to Private-sector Data in India, 2(4) International Data Privacy Law 302-315 (2012).

Amin, Ratnawati Mohd \& Gardner, Robin, Open Access to Legal Material in South East Asia and its Neighbors, 40 International Journal OF LEGAL INFORMATION 309 (2012).

Creemers, Rogier, Media Control with Chinese Characteristics, in RoutLedge Handbook of Media Law (Monroe E. Price, Stefaan Verhulst \& Libby Morgan eds., Routledge 2012).

Helge, Kris, Success of a Nation's Soccer Team: A Bellwether Regarding a Nation's Electronic Information Infrastructure, the Legal Regulations that Govern the Infrastructure, the Resulting Citizen-Trust in its Government and its E-Readiness in Nigeria, the DPRK, China, 39(3) Northern Kentucky Law Review 467-534 (2012).

Hsieh, Hsiang-Yang, Locating the Value of Information Privacy in a Democratic Society: A Study of the Information Privacy Jurisprudence of Taiwan's Constitutional Court, 7(1) National TaIwan University LAW REview 293 (2012).

Ismail, Noriswadi, Selected Issues Regarding the Malaysian Personal Data Protection Act (PDPA) 2010, 2(2) International Data Privacy LAW 105-112 (2012).

Kulesza, Joanna, International Internet Law (Routledge 2012).

Madi, Ramzi, Internet Surfing in Jordan: Overviews and Monitoring, 26(2) Arab LaW Quarterly 241-247 (2012).

Mazzarella, William \& Kaur, Raminder, Between Sedition and Seduction: Thinking Censorship in South Asia, in Routledge Handbook of Media Law (Monroe E. Price, Stefaan Verhulst \& Libby Morgan eds., Routledge 2012).

McKenna, Caroline E., India's Challenge: Preserving Privacy Rights While Implementing an Effective National Identification System, 38(2) Brooklyn Journal of International Law 729 (2012).

Mendoza, Charisse Mae V., Balancing of Interest in the Digital Age: Protection of the Rights of Offended Parties and the Constitutional Rights 
of the Accused in the Context of Sex Scandals, 86(2) Philippine Law JOURNAL 356-404 (2012).

Rahman, Rizal, The Legal Measure against Denial of Service (DoS) Attacks Adopted by the United Kingdom Legislature: Should Malaysia Follow Suit?, 20(2) International Journal of LAW \& INFOrMation Technology 85-101 (2012).

Shao, Guosong, Internet Law in China (Chandos 2012).

Tao, Qian, The Knowledge Standard for the Internet Intermediary Liability in China, 20(1) International Journal of LAW \& Information Technology 1-18 (2012).

Tsuchiya, Motohiro, Systematic Government Access to Private-sector Data in Japan, 2(4) International Data Privacy Law 239-244 (2012).

Wang, Zhizheng, Systematic Government Access to Private-sector Data in China, 2(4) International Data Privacy Law 220-229 (2012).

Watson, Keith D., The Tor Network: A Global Inquiry into the Legal Status of Anonymity Networks, 11 Washington University Global Studies LaW Review 715-737 (2012).

Yang, Guobin, Social Dynamics in the Evolution of China's Internet Content Control Regime, in Routledge Handbook of Media Law (Monroe E. Price, Stefaan Verhulst \& Libby Morgan eds., Routledge 2012).

Zakri, Izura Masdina, Internet Law: Latest Developments in Cyber Laws in Malaysia, 40 International Journal of Legal Information 257 (2012).

\section{AIR AND SPACE}

Aoki, Setsuko, Japanese Space Activities Act in the Making, 61(1) GermaN Journal of Air \& Space Law 111 (2012).

Arafah, Adhy Riadhy, Sovereign Right Claim on Geo Stationary Orbit (GSO), 2(2) Indonesia Law Review 163 (2012).

Delgado-López, Laura M., Sino-Latin American Space Cooperation: A Smart Move, 28 Space Policy 7-14 (2012). 
García-Arboleda, José Ignacio, Report on the 2012 IATA Legal Symposium, Shanghai, China, 5-7 February, 37(3) Air \& SpaCe Law 281-284 (2012).

George, Moses, Aerodrome Certification and Airport Privatisation in India, 61(1) German Journal of Air \& Space Law 129 (2012).

Latipulhayat, Atip \& Ariananto, Agil, Legality of the European Union Flight Ban Towards Indonesian Airlines, 2(2) International Journal of Public LaW \& Policy 149-161 (2012).

Maria Pozza, Emerging Space Powers: The New Space Programs of Asia, the Middle East and South America, 28(4) Space Policy 304-305 (2012).

Palkovitz, Neta, EL-AL's Liability for Claims Related to Security Services in the Israeli Context: Between Exclusivity and Domestic Policy, 37(3) Air and Space Law 213-230 (2012).

Qin, Huaping, Dealing with Unruly Behavior on Board Aircraft: A Chinese Perspective, 27(2) Korean Journal of Air \& Space LaW \& Policy 193 (2012).

Robinson, Jana, Forging a Closer Europe-Japan Strategic Partnership: The Space Dimension, 28 Space Policy 218 (2012).

Tan, Alan Khee-Jin, The 2010 ASEAN-China Air Transport Agreement: Placing the Cart Before the Horse?, 37(1) Air and Space Law 35-50 (2012).

Zhu, Lijing, The Legal Personality of the Asia-Pacific Space Cooperation Organization, 1(1) AALCO Journal of International LaW 159 (2012).

\section{MISCELLANEOUS}

Ballakrishnen, Swethaa, I Love my American Job: Professional Prestige in the Indian Outsourcing Industry and Global Consequences of an Expanding Legal Profession, 19 International Journal of the Legal Profession 379-404 (2012).

Lee, Tahirih V., Orienting Lawyers at China's International Tribunals Before 1949, 27 Maryland Journal of International Law 179214 (2012). 
Schiller, Sabina, A New Global Legal Order, With or Without America: The Case for Accrediting Foreign Law Schools, 26(1) Emory InTeRNational LaW Review 411-448 (2012). 